\title{
National Pride and Social Trust in Russia in Cross-National Comparative Perspective ${ }^{1}$
}

\author{
Marharyta Fabrykant \\ HSE University, Belarusian State University \\ marharyta.fabrykant@gmail.com,mfabrykant@hse.ru
}

\begin{abstract}
National pride and social trust are often perceived and used as alternative grounds for social cohesion. While national pride is essentially exclusive, because shared only by compatriots, trust in social institution is not, and the general interpersonal trust measured as trust in strangers is inclusive by definition. These differences create an opportunity for a variety of interrelations between national pride and various dimensions of social trust, depending on how certain kinds of individuals and institutions are perceived in relation to a country's identity. This paper presents the results of a research examining interrelations between national pride and social trust in Russia compared to other countries. The empirical data used in the research come from the most recent wave of the World Values Survey, released in 2020. The results show that in Russia, national pride is positively related to trust in all major social institutions, including even international organizations. This pattern is observed in most countries (with the notable exception of the USA, where correlations between national pride and trust in some institutions, such as the press and the $\mathrm{UN}$, are negative). These positive correlations in Russia are the strongest for trust in the churches, the armed forces, and the government; in most other countries, the pattern is similar but much less pronounced: the relation to trust in other institutions is not that weaker. The relation of national pride to various dimensions of interpersonal trust reveals a deeper difference: unlike in most countries, in Russia, national pride has no negative relation to trust in people of another nationality or religion but is significantly negatively related to strangers. Thus, apparently Russian scoring high on national pride are more ready to accept people with any kind of identity, however different from their own, than people whose identity is unknown and undefined.
\end{abstract}

Key words: national pride, social trust, Russia, interpersonal trust, institutional trust.

\section{Introduction}

Much of the research on social cohesion relies on a contrast between the two mechanisms keeping society together. In traditional societies, macrosocial solidarities are frequently portrayed as an extension of a sense of belonging to a tightly knit circle of a family and more broadly defined familiar persons, famously captured in nations and nationalism studies as an imagined community (Anderson, 2006). This imagery is reinforced by a self-serving in-group bias turning a collective identity into a valuable source of positive self-esteem (Turner, Brown, Tajfel 1979). In modern

\footnotetext{
${ }^{1}$ This work is an output of a research project implemented as a part of the Basic Research Program at the HSE University
} 
societies, social cohesion is based not on perceived similarity and unity within the in-group, but on social trust - trust in various people, including total strangers, in a diverse and pluralist society and trust in abstract institutions functioning according to generalized rational principles as opposed to national loyalties based on the sense of tradition and shared cultural heritage (Inglehart \& Baker, 2000; Janmaat, 2011; Uslaner, 2012). While the relation of trustworthy institutions and high interpersonal trust to higher level of at least economic development is long established (Bjørnskov, 2012; Mikucka, Sarracino, Dubrow, 2017), its logic, and even the answer to the question what comes first, increase in trust or economic growth, remains uncertain (Safra, Chevallier, Grèzes, Baumard, 2020). In the real-life modernizing societies, as opposed to the traditional vs. modern ideal types, the two grounds for social cohesion are not so much exclude each other as coexist and, as shown by the renaissance of nationalism in the last several years, intertwine in a variety of ways. The question of this research aims to answer is, how national pride as a positive aspect of national identity and social trust, institutional as well as interpersonal, relate to each other.

The issue of interrelation between national pride and social trust is particularly relevant for Russia. On the one hand, as a modernizing middle-income country, Russia looks like a perfectly representative case for studying the coexistence of the two grounds for social cohesion. On the other hand, over the last decades, Russia has undergone dramatic and heterogeneous changes in the level of national pride not found in most other countries (Fabrykant \& Magun, 2019). Getting to understand the extent to which interrelations between national pride and institutional and interpersonal trust in Russia reflect the general logic of modernization vs. the country's unique historic trajectory has a potential of making an important contribution to the understanding of the role national pride as a source of social cohesion and of the social dynamics of the contemporary Russia. The goal of the present research is to probe into this issue by means of testig the following hypotheses.

Hypothesis 1a. Institutional trust in Russia is positively related to national pride. These correlations are the strongest for the state institutions, weaker, for non-state institutions, and the weakest, for international organizations.

Hypothesis $1 b$. Interpersonal trust is positively related to national pride for trust in relatives and acquaintances, negatively, to strangers, and more strongly negatively, to trust in people of another nationality. The positive correlations for interpersonal trust are on average weaker than those for institutional trust.

Hypothesis $2 a$. The relation of national pride to institutional confidence in Russia over the last decades has been growing stronger for the state institutions and weaker, for non-state domestic institutions and international organizations. 
Hypothesis $2 b$. The relation of national pride to interpersonal trust over the last decades has been growing weaker for trust in relatives and acquaintances (hypothesized positive correlations) and stronger, for trust in strangers and people of another nationality (hypothesized negative correlations).

Hypothesis 3. The relation of national pride to both institutional and interpersonal trust in Russia compared to other countries is average or higher because of Russia's relatively high Human development Index (HDI) and the stronger positive relation between the HDI and institutional trust and weaker negative relation between the HDI and trust towards people of other nationality.

\section{Data and Methods}

The individual level data of the World Values Survey (WVS), which is a major crossnational survey covering a variety of issues. National pride is represented in the survey via a direct question "How proud are you to be [country's nationality]?" with the answer options "very proud", "quite proud", "not very proud", "not at all proud". Institutional trust is measured by a set of items under the following question: "I am going to name a number of organizations. For each one, could you tell me how much confidence you have in them: is it a great deal of confidence, quite a lot of confidence, not very much confidence or none at all?" Respondents are invited to answer this question for each of the following institutions: the [churches] (substituted with a country-specific name), the armed forces, the press, labor unions, the police the courts, the government, political parties, parliament, the civil service, major companies, environmental organizations, The [European Union] (substituted for a country-specific major international organization; in Russia this item features in two versions - for the CIS and the European Union), the United Nations. The set of items on interpersonal trust is formulated by means of the following questions: "I'd like to ask you how much you trust people from various groups. Could you tell me for each whether you trust people from this group completely, somewhat, not very much or not at all?" The items include "your family", “your neighborhood”, "people you know personally", "people you meet for the first time", "people of another religion", "people of another nationality".

The hypotheses 1 and 3 were tested using the most recent wave of the survey - the joint WVS-EVS (European Values Study) dataset of the seventh wave covering the period between the 2017 and 2020 and containing data collected in 78 countries including Russia (EVS/WVS, 2020). To test the hypothesis 2 , the times series dataset including the earlier waves of the WVS was added. (Inglehart et al., 2020) Russia features in five out of seven waves of the WVS. The data on institutional pride compatible with those in the most recent wave are also available for the second (1989-1993), the third. (1994-1998), the fifth (2004-2009), and the sixth (2010-2014) waves, and for interpersonal trust, for the fifth (2004-2009) and the sixth (2010-2014) waves. 
The research was conducted in the following way. First, correlations between national pride and various dimensions of institutional and interpersonal trust in Russia were computed on the most recent data available to test the hypothesis 1 and for the earlier waves to test the hypothesis 2. Then, to test the hypothesis 3, the between national pride and various dimensions of trust correlations were computed for all the other countries covered by the most recent WBS wave. The suggested explanation of the Russian case compared to other countries was tested by means of a series of multilevel ordinal logistic regression models for each of the dimensions of institutional and interpersonal trust represented in the survey. Each model included a dimension of trust as a dependent variable and the same set of independent variables - national pride as an individual level predictor, a set of individual level control variables (age in years, gender as a male/female dichotomy, education level as an eight-point ISCED scale, and income level as a 10-point scale), inequality-adjusted Human development Index (IHDI, taken from the United Nations development Program dataset for 2019) as a country level predictor, and a cross-level interaction term to test for an interaction effect between national pride and the HDI. To make the main effect of national pride meaningful, the lowest score on the IHDI presented in the sample was subtracted from each country score. Thus, the main effect in each model applies to the country with the lowest IHDI in the sample, and not to a hypothetical non-existent country with the IHDI of 0 .

\section{Results}

Correlations between national pride and various facets of institutional and interpersonal trust in Russia are shown in the figures 1 and 2. As expected, the correlations between national pride and trust in all kinds of institutions represented in the survey are positive and most of them, statistically significant. They vary considerably in their strength, and the differences correspond to the hypothesis 1a: the correlations with the state institutions are the strongest and with the international organizations, the weakest and non significant. Interestingly, the strongest correlation is found for trust in the armed forces, with the government and the churches sharing the second position, and the parliament and political parties, and the civic services, the third.

The correlations between national pride and interpersonal trust only partly correspond to the hypothesis $1 \mathrm{~b}$. For trust in the family, the neighborhood, and acquaintances, correlations are positive as expected, for people of another religion, so much weaker as to be non-significant, and for trust in strangers, negative. Unexpectedly, however, the correlation with trust in people of another nationality is positive.

As can be seen in the figures 3 and 4, the correlations between national pride and trust are the strongest for the kinds of institutions and persons enjoying the highest net level of trust. For institutional trust, the level of trust in these institutions in Russia is significantly higher than on 
average in all the 78 countries covered in the survey, while for interpersonal trust, the level of trust in Russia is rather close to the cross-national average on all the six dimensions.

To see how typical these correlations are and how Russia stands on them vis-à-vis other countries, let us turn to the results shown in the figures 5-25. These figures show that Russia scores rather higher than most other countries on the correlations of national pride to all the five institutions where the within-country comparison has shown the strongest correlation, namely trust in the armed forces, the government, the churches, the political parties, the parliament, and the civic services. Nevertheless, on each of these correlations, there are at least ten countries scoring higher, so Russia's position is not extreme. As for the other institutions, Russia occupies a middle position on the correlation between national pride and trust in the police, while for the correlation with trust in the press, Russia's position is relatively high. The correlation of national pride with trust in the justice system in Russia compared to other countries is average and to trust in the environment protection movement and trust in the labor unions, relatively high. The correlation between national pride and trust in the major companies in Russia compared to other countries, is, on the contrary, rather low but still, unlike in some countries, positive. The latter also applies to the trust in the international organizations - the CIS, the United Nations, and even to the European Union, where the correlation is also positive, unlike for a considerable number of countries including some EU-members.

As regards interpersonal trust, Russia scores about average on the strength of the positive correlation of national pride to trust in the family, slightly lower than average, to trust in the neighborhood, and slightly higher than average, to trust in people known personally. As for the correlation of national pride to trust in people met for the first time, people of another religion, and people of another nationality, on each of these, about half of the countries has a positive and another half, a negative correlation. Russia falls almost exactly in between the two by showing very week correlations for trust in people met for the first tie and people of another religion, while the correlation of national pride is strong enough to place Russia distinctly into the category of the countries where this correlation is positive, although in most countries in this category the correlation is somewhat stronger.

Thus, the correlations of national pride to institutional and interpersonal trust in Russia compared to other countries are average on some dimensions, stronger or weaker than average on others, but never atypical, which is rather close to the hypotheses $2 \mathrm{a}$ and $2 \mathrm{~b}$.

The dynamics of the correlations between national pride and institutional and interpersonal trust is shown in the figures 26 and 27. Most facets of institutional trust follow the same pattern: the decrease roughly between the late 1980s and the late 2000s followed the by an increase between the 2010s and the present. This pattern is particularly visible for the correlation between 
national pride and trust in major companies where the initially correlation turns negative, and them becomes positive again. It is also worth mentioning that on nearly all of these facets, with the exceptions of trust in the environment protection movement and in the press, the regained positive correlations are considerably weaker than the initial ones.

For the interpersonal trust, the same dynamics of decrease followed by increase is revealed for the correlations of national pride to trust in the neighborhood and people known personally. The other correlations demonstrate a consistent decrease - for rust in people met for the first time, from positive to negative and for trust in people of another religion and of another nationality, from stronger to weaker positive correlations. These results run contrary to the hypothesis 3 .

To see whether the correlations of national pride to institutional and interpersonal trust in Russia compared to other countries are due to the reason suggested in the hypothesis 3, let us examine the regression models presented in the tables 1 and 2. He expected positive interaction effect of national pride and the IHDI is revealed in some but not all the models. For institutional trust, this interaction effect is positive for trust in the armed forces and the police, negative, for trust in the press, labor unions, civil services, major regional organizations, environment protection movements, the justice system, and the United Nations. For the remaining institutions, most notably the government, the interaction effects are non-significant.

The same diversity of patterns also applies to the models for interpersonal trust. The hypothesized positive interaction effect is found only in one model- that for trust in the family. The interaction effects for trust in the neighborhood and people met first time, while the interaction effects for people know personally, people of another religion, and, most importantly, people of another nationality are non-significant. Thus, the results are only partly in accord with the hypothesis 3.

\section{Conclusions}

He obtained results show that, as expected, national pride in Russia is the most strongly related to state institutions as opposed to non-governmental and international organizations and familiar people as opposed to strangers or foreigners. Compared with 77 other countries, Russia demonstrates more or less average scores on all these correlations. The profile of national identity is predominantly statist but not much more so than in many other countries, and even trust in international organizations in Russia, unlike in some other countries, is not negatively related to national pride. This most noteworthy distinction of Russia is a rather weak correlation between national pride and trust in the major companies. Another interesting feature is the strongest correlation between national pride and trust in the armed forces, stronger even than for trust in the government, bringing to memory the famous saying of the army and fleet as Russia's only two 
allies. This correlation, however, is stronger still in some other ex-empires, such as the Great Britain and Spain, the neutral Finland, and the countries as different form each other as the US and Iraq.

The "raising up from the knees" rhetoric more obviously presents itself in the dynamics of the initial decrease and the subsequent decrease in the relation of national pride to institutional trust. Thus, national identity becomes first deinstitutionalized and them, reinstitutionalized to an extent compatible to the global average but rather lower than at the initial point. This profile of Russia as a "normal country" in Shleifer and Treisman's (2005) meaning of the word is, however, due primarily not to Russia belonging to middle-income countries. The research findings demonstrate that, differences in country scores on human development affect the relation of national pride to various facets of institutional and interpersonal trust in different ways. Interestingly, the expected stronger positive relations are found for trust in only two institutions, the armed forces and the police, both of which demonstrate the state monopoly for legitimate violence. It may be due to the fact that in the more advanced countries according to the modernization theory, national pride become less of a mainstream social norm and more of a traditionalist, conservative position, which its higher emphasis on the traditional ways of maintaining law and order. At the same time, many other institutions are perceived less as attributes of a nation-state and more as representatives of diverse groups in an increasingly complex society. The relation of trust in the government to national pride does not depend on the IHDI, and given its considerable variety across countries, its factors remain to be found.

Arguably the most interesting result is obtained for interpersonal trust, and specifically, for trust in people of another nationality. Contrary to what might have been expected, its relation to national pride is negative in only approximately in a half of the countries, and Russia falls into another half. Contrasted to a negative correlation with trust in people met for the first time, this positive relation may reflect an attitude placing the significance of nationality as such above specific national belonging. This prevalence of a nation over the nation sheds some light on the paradoxical "nationalist international" observed in the political sphere over the last years in particular. The reasons why this phenomenon appears in some countries and not in others requires and deserves a research of its own.

\section{References}

Anderson, B. (2006). Imagined communities: Reflections on the origin and spread of nationalism. Verso books. 
Bjørnskov, C. (2012). How does social trust affect economic growth?. Southern Economic Journal, 78(4), 1346-1368.

EVS/WVS (2020). European Values Study and World Values Survey: Joint EVS/WVS 2017-2021 Dataset (Joint EVS/WVS). JD Systems Institute \& WVSA. Dataset Version 1.0.0, doi: $10.14281 / 18241.2$

Fabrykant, M., \& Magun, V. (2019). Dynamics of National Pride Attitudes in Post-Soviet Russia, 1996-2015. Nationalities Papers, 47(1), 20-37.

Inglehart, R., \& Baker, W. E. (2000). Modernization, cultural change, and the persistence of traditional values. American sociological review, 19-51.

Inglehart, R., Haerpfer, C., Moreno, A., Welzel, C., Kizilova, K., Diez-Medrano J., M. Lagos, P. Norris, E. Ponarin \& B. Puranen et al. (eds.). 2020. World Values Survey: All Rounds Country-Pooled Datafile. Madrid, Spain \& Vienna, Austria: JD Systems Institute \& WVSA Secretariat [Version: http://www.worldvaluessurvey.org/WVSDocumentationWVL.jsp].

Janmaat, J. G. (2011). Social cohesion as a real-life phenomenon: Assessing the explanatory power of the universalist and particularist perspectives. Social Indicators Research, 100(1), 61-83.

Mikucka, M., Sarracino, F., \& Dubrow, J. K. (2017). When does economic growth improve life satisfaction? Multilevel analysis of the roles of social trust and income inequality in 46 countries, 1981-2012. World Development, 93, 447-459.

Safra, L., Chevallier, C., Grèzes, J., \& Baumard, N. (2020). Tracking historical changes in trustworthiness using machine learning analyses of facial cues in paintings. Nature communications, 11(1), 1-7.

Shleifer, A., \& Treisman, D. (2005). A normal country: Russia after communism. Journal of Economic Perspectives, 19(1), 151-174.

Turner, J. C., Brown, R. J., \& Tajfel, H. (1979). Social comparison and group interest in ingroup favouritism. European journal of social psychology, 9(2), 187-204.

Uslaner, E. M. (2012). Segregation and mistrust: Diversity, isolation, and social cohesion. Cambridge University Press. 


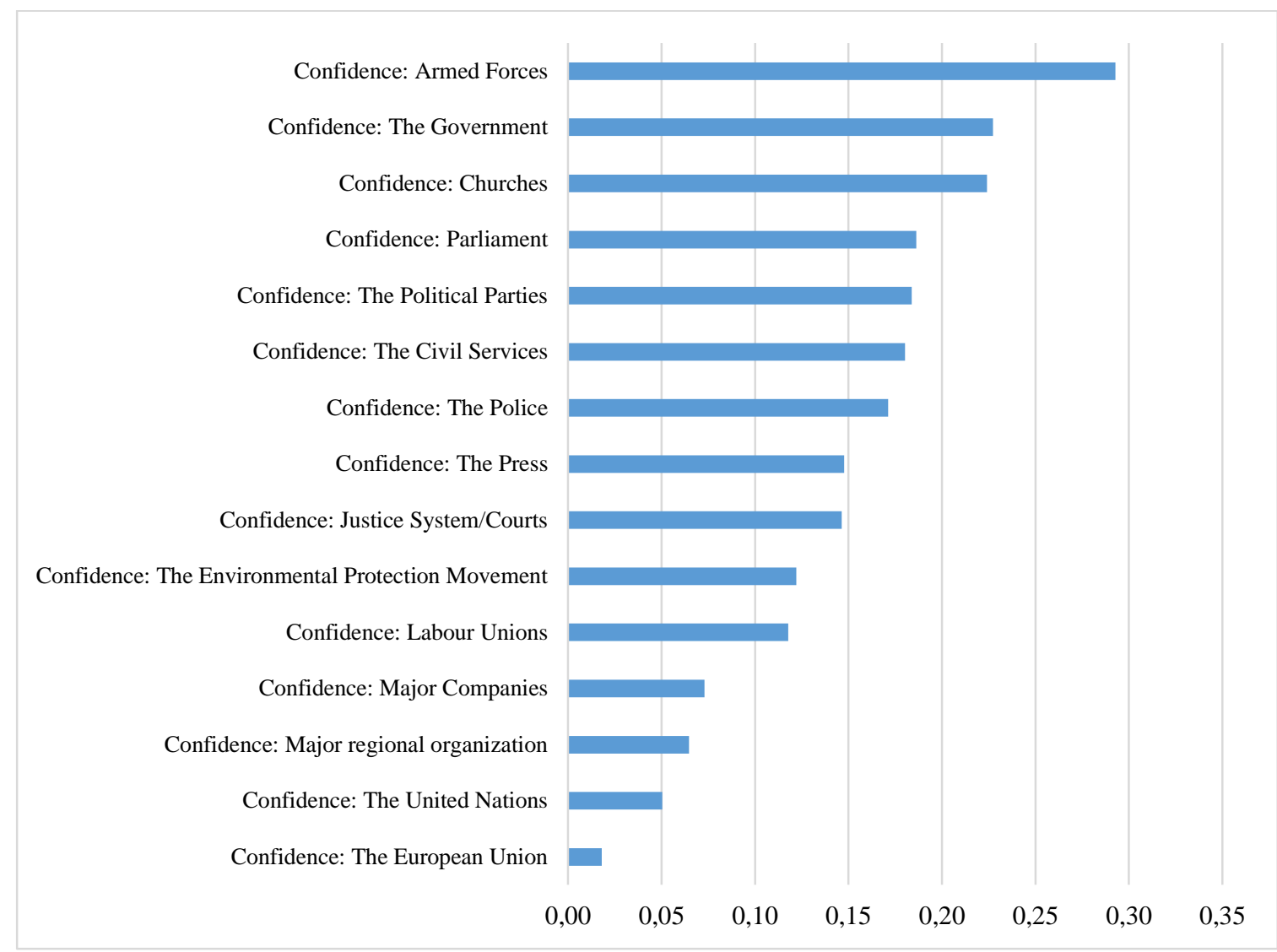

Figure 1. Correlations between national pride and trust in various institutions in Russia

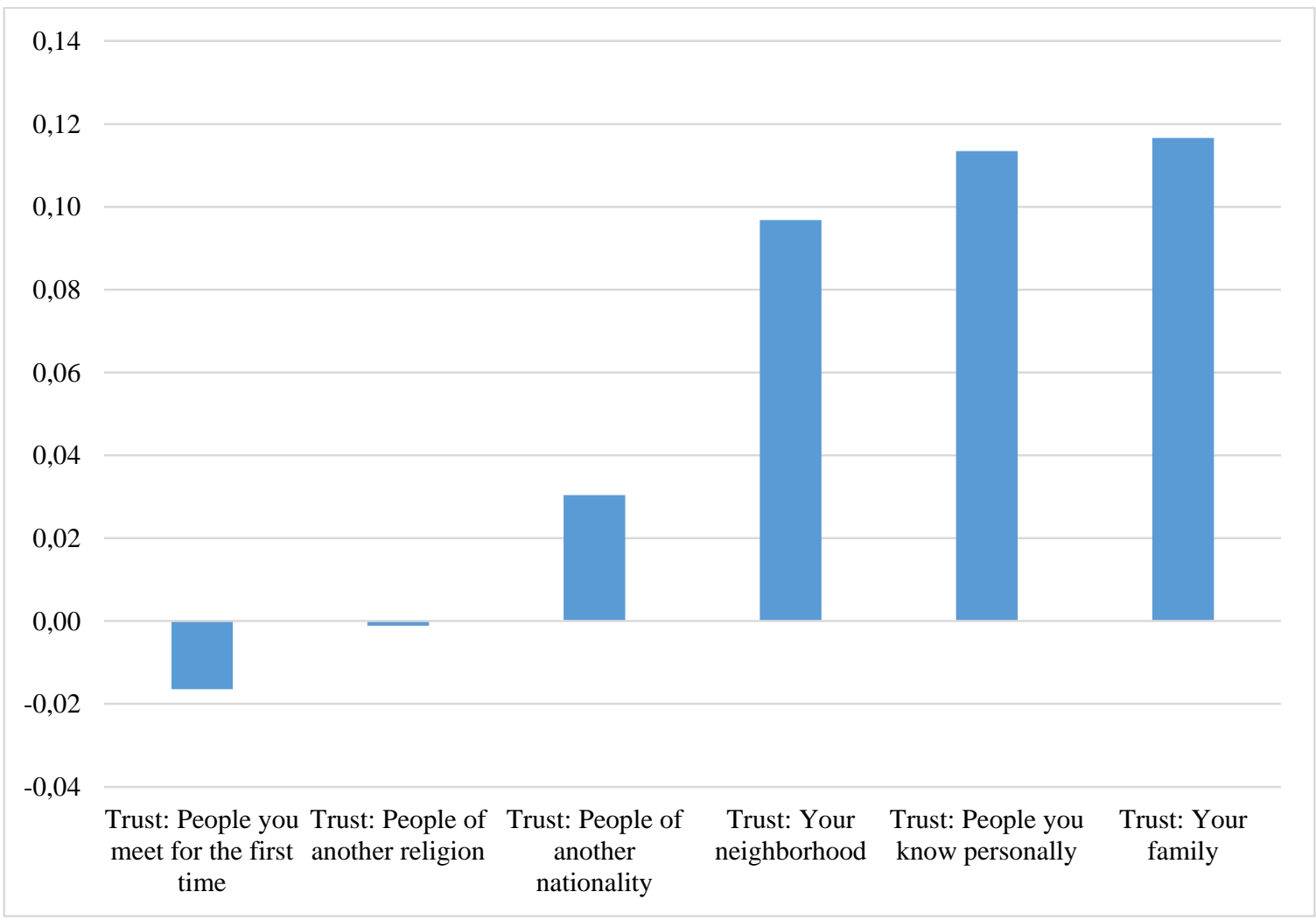

Figure 2. Correlations between national pride and various facets of interpersonal trust in Russia 


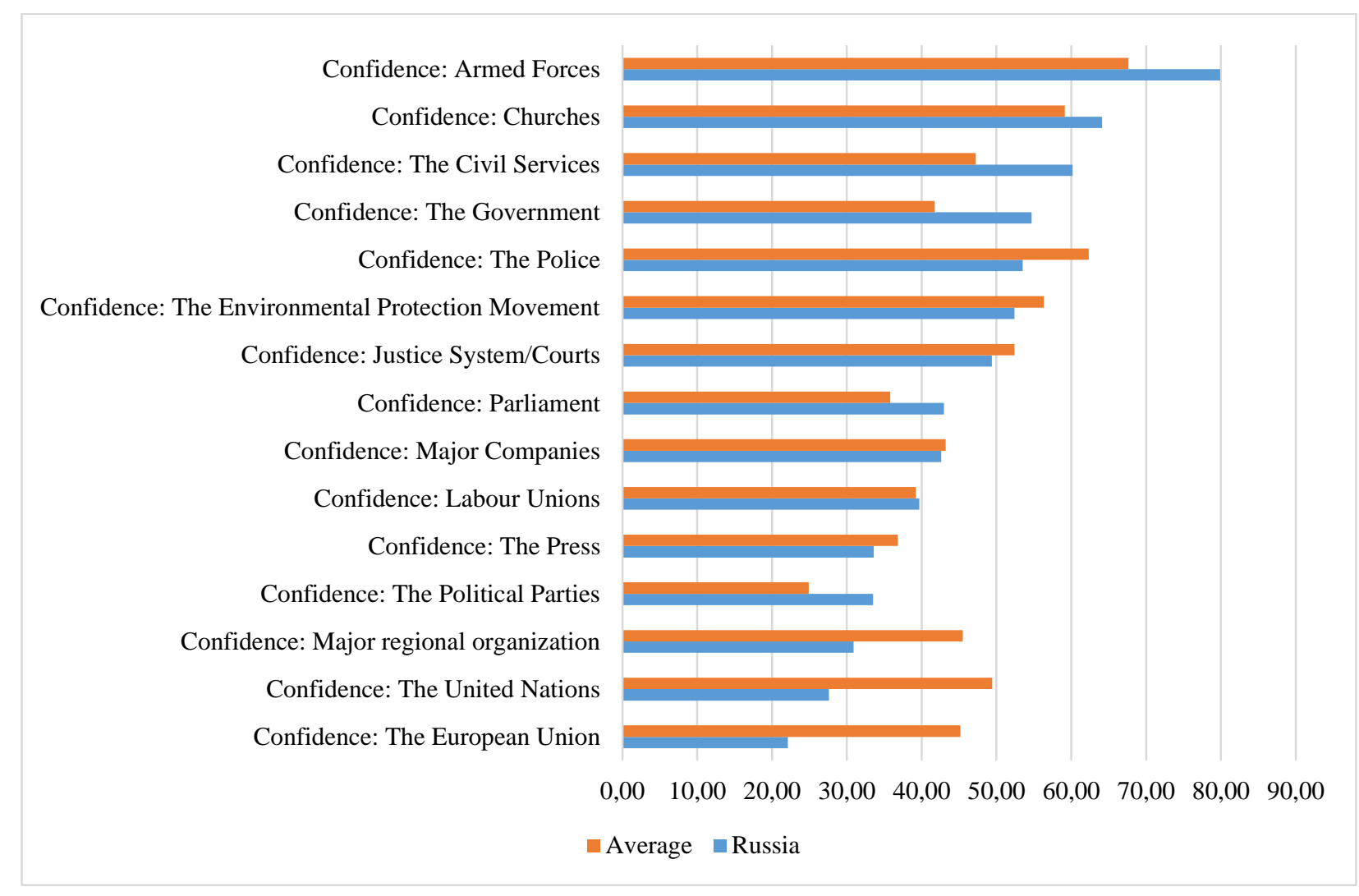

Figure 3. The level of institutional trust in Russia vs. the average level for 77 other countries (the percentage of those who trust or trust strongly)

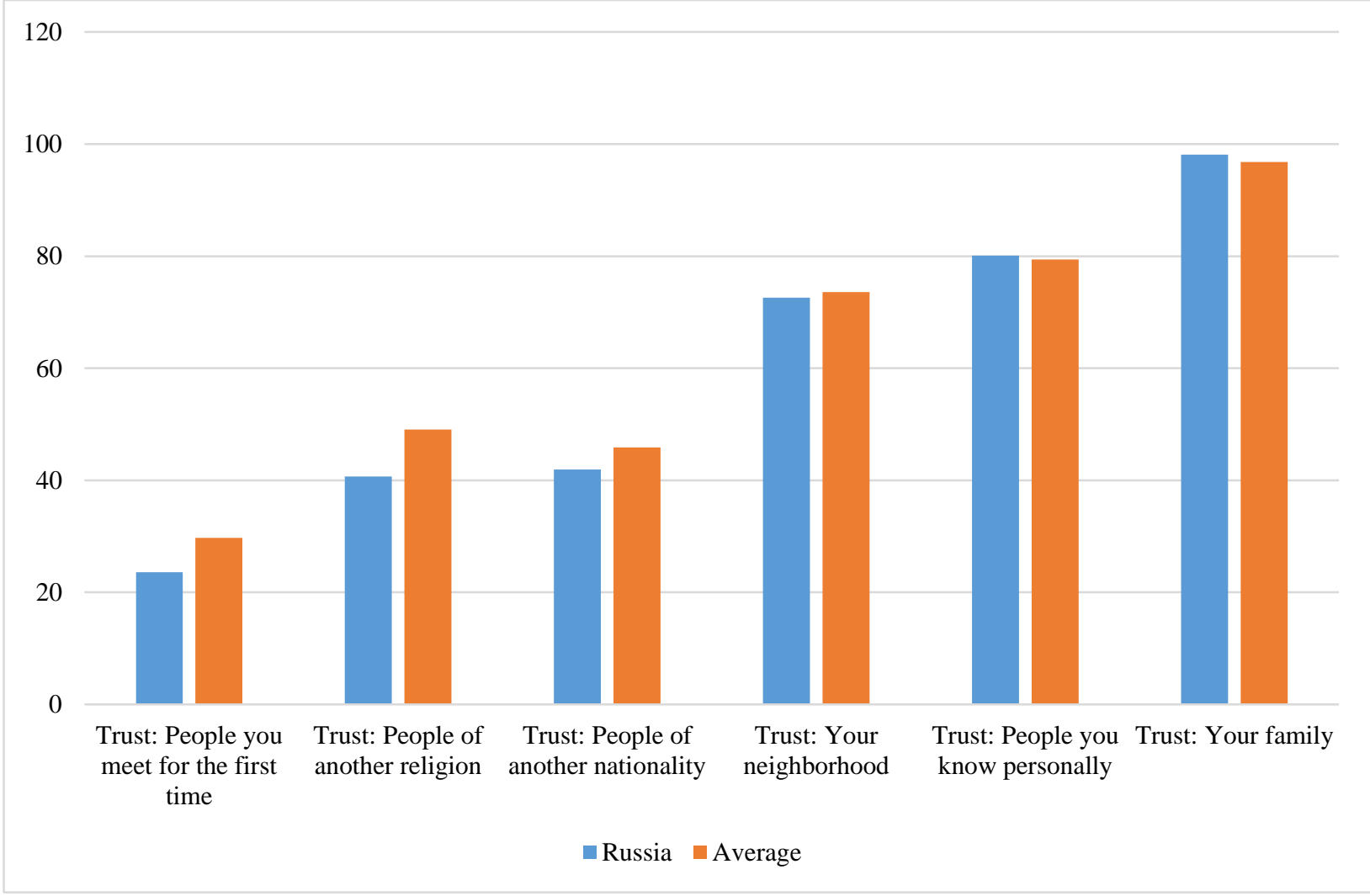

Figure 4. The level of interpersonal trust in Russia vs. the average level for 77 other countries (the percentage of those who trust or trust strongly) 


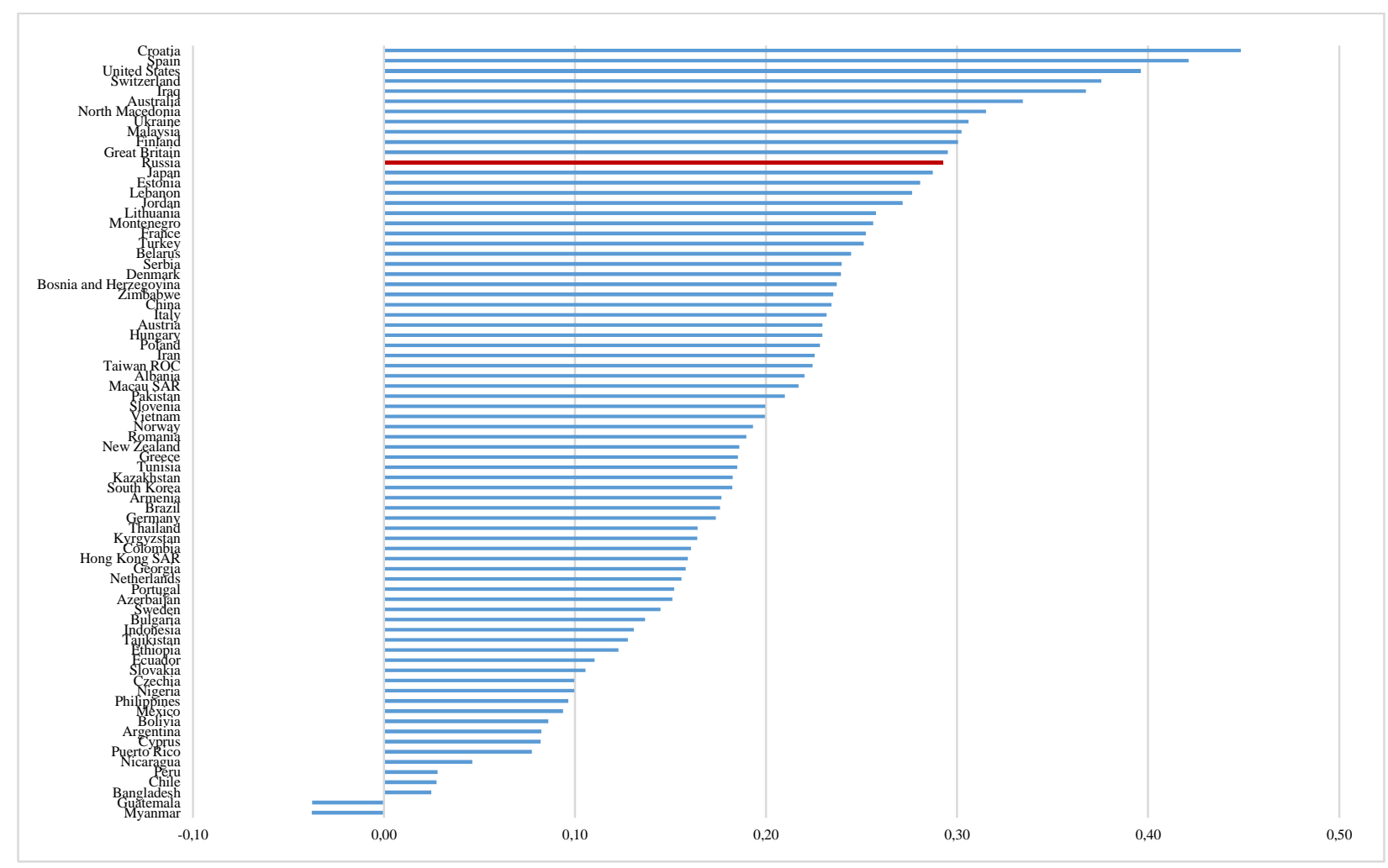

Figure 5. Correlations between national pride and trust in the armed forces by countries

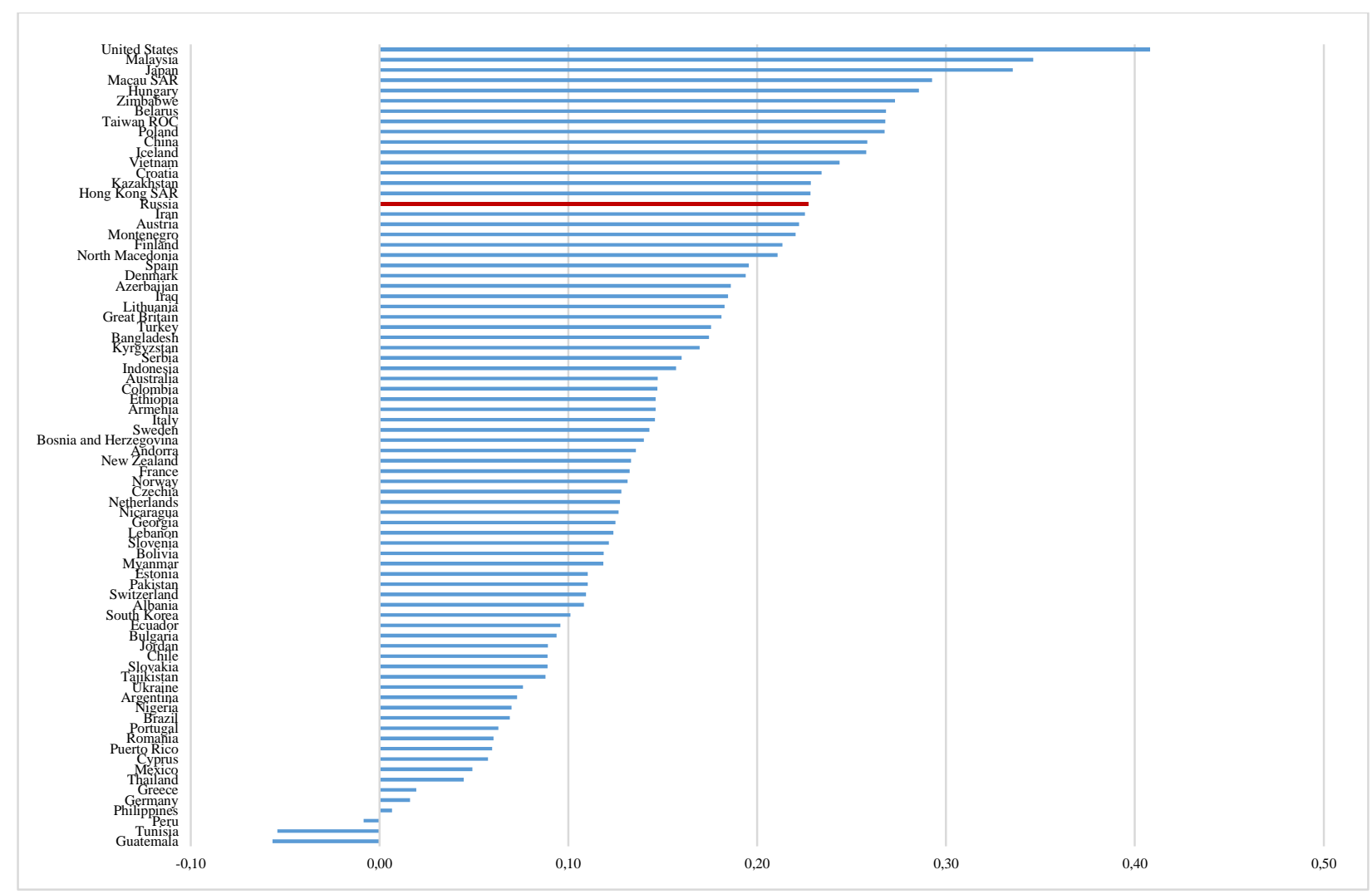

Figure 6. Correlations between national pride and trust in the government by countries 


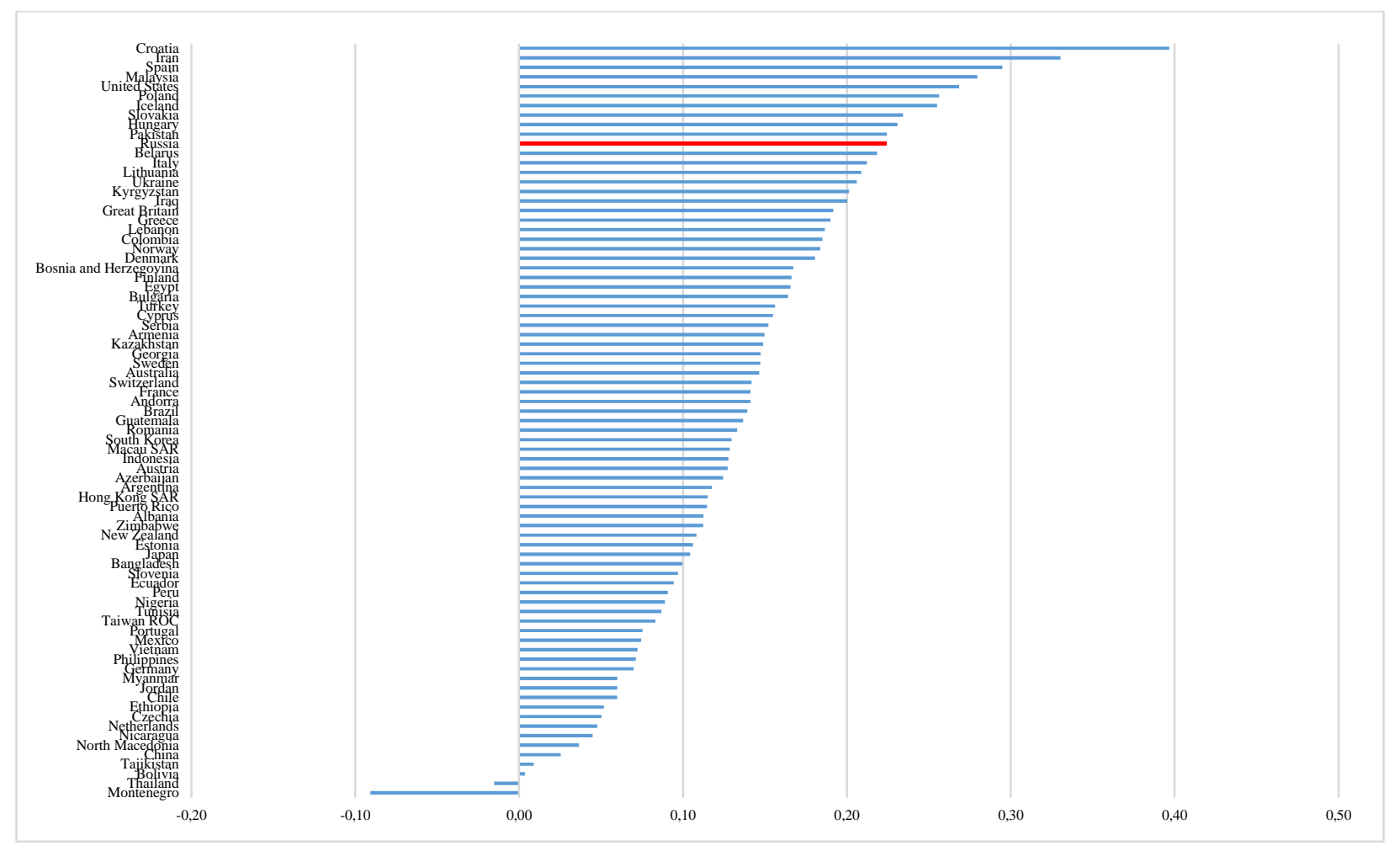

Figure 7. Correlations between national pride and trust in the churches by countries

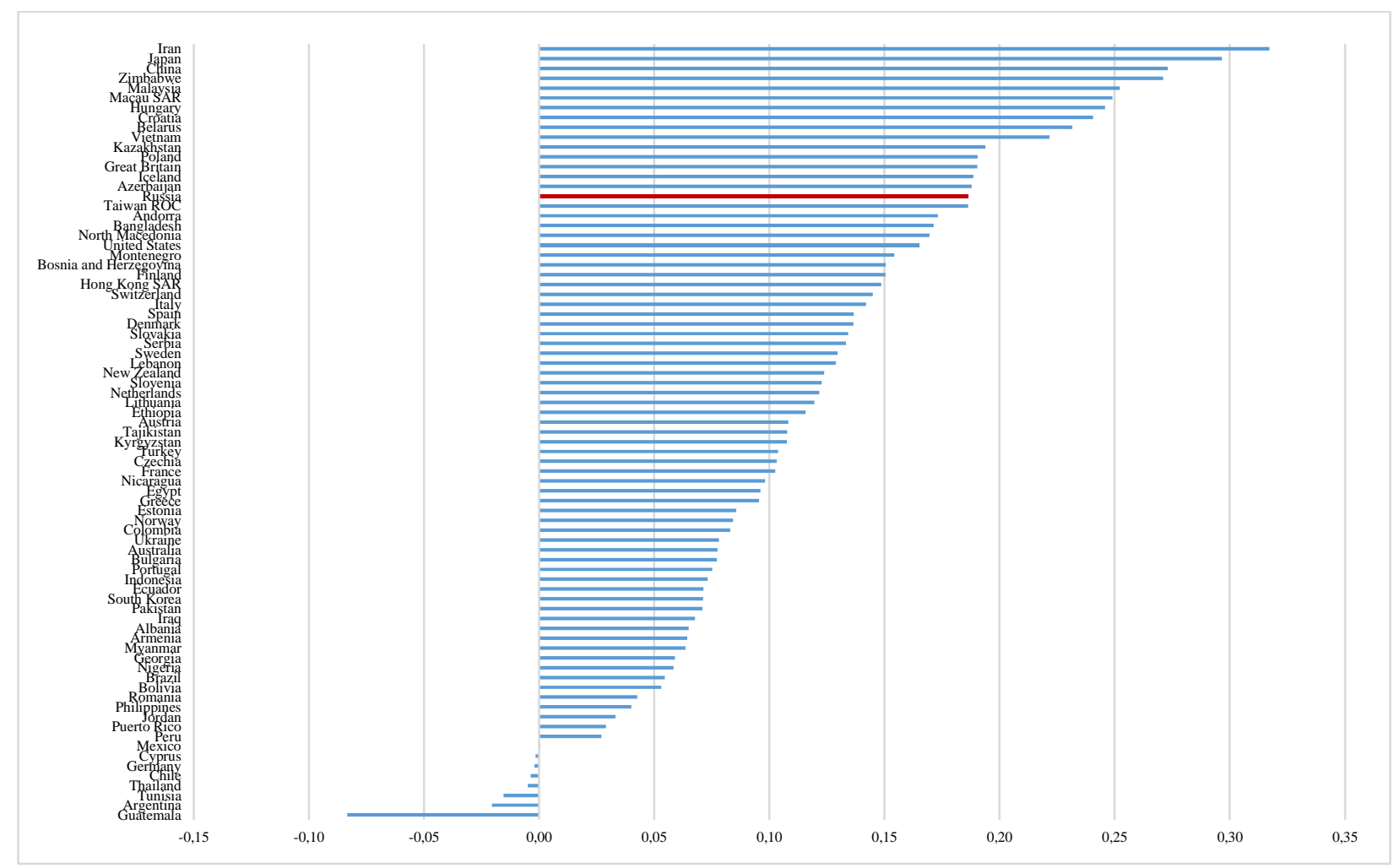

Figure 8. Correlations between national pride and trust in the parliament by countries 


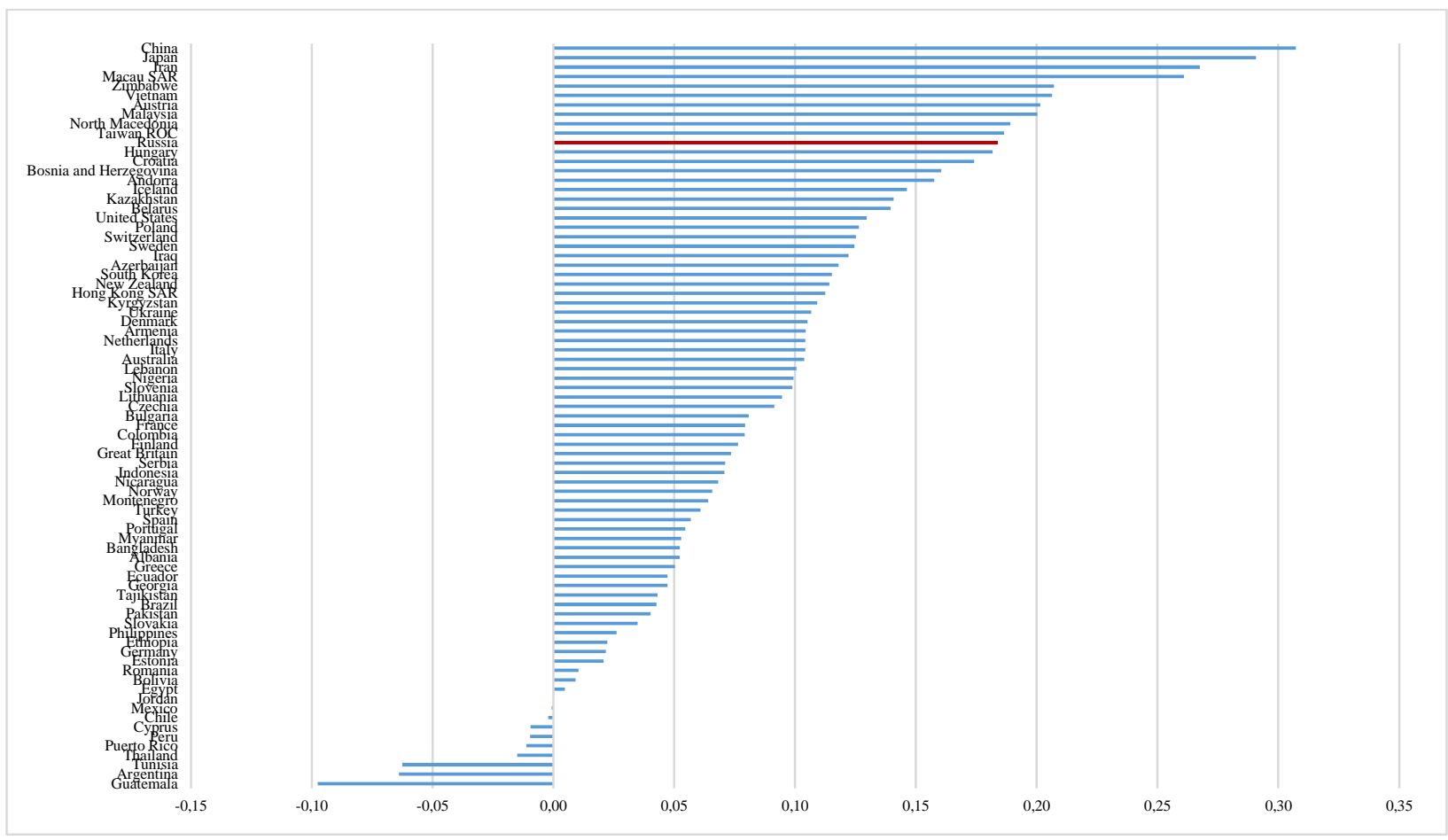

Figure 9. Correlations between national pride and trust in the political parties by countries

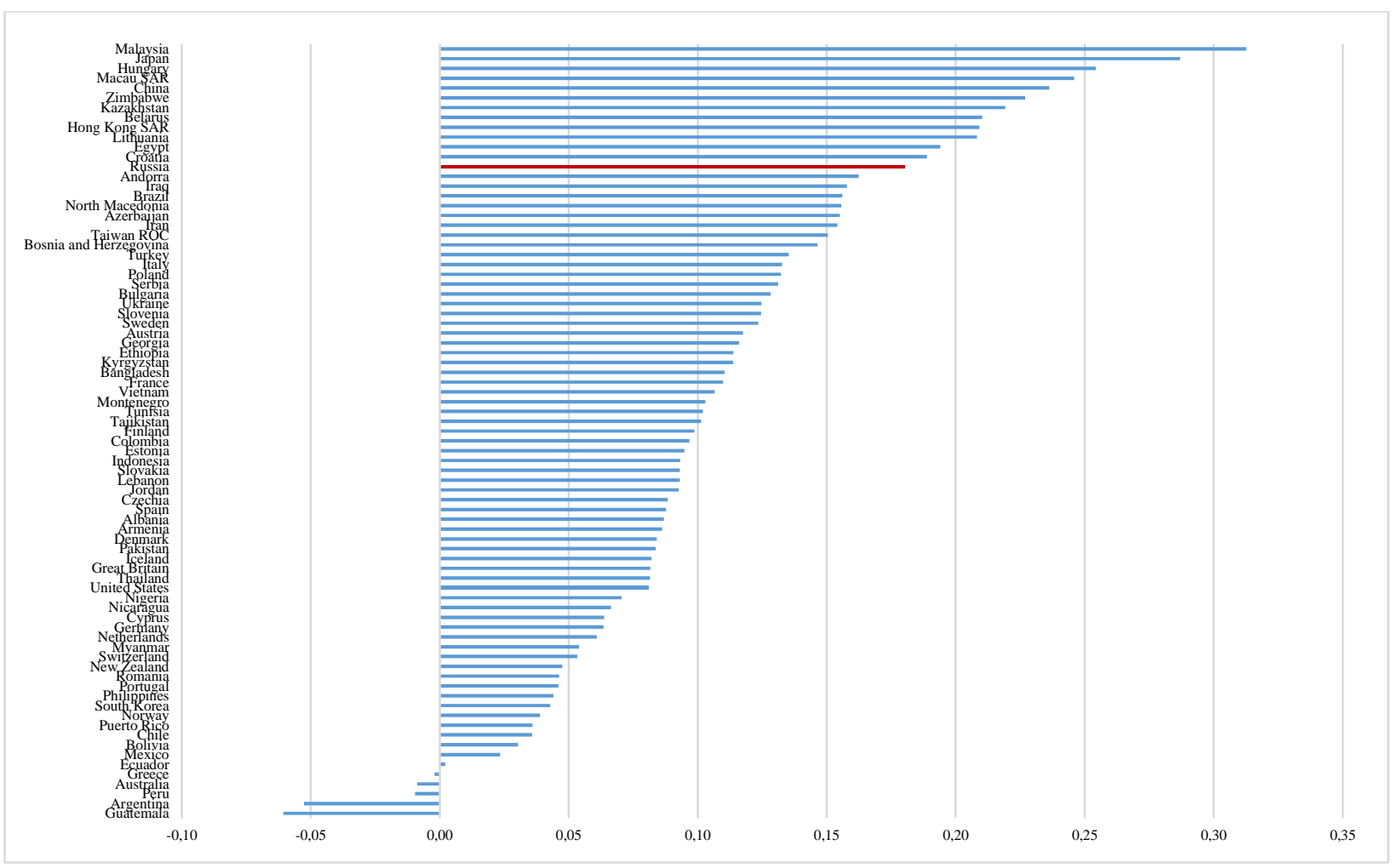

Figure 10. Correlations between national pride and trust in the civil services by countries 


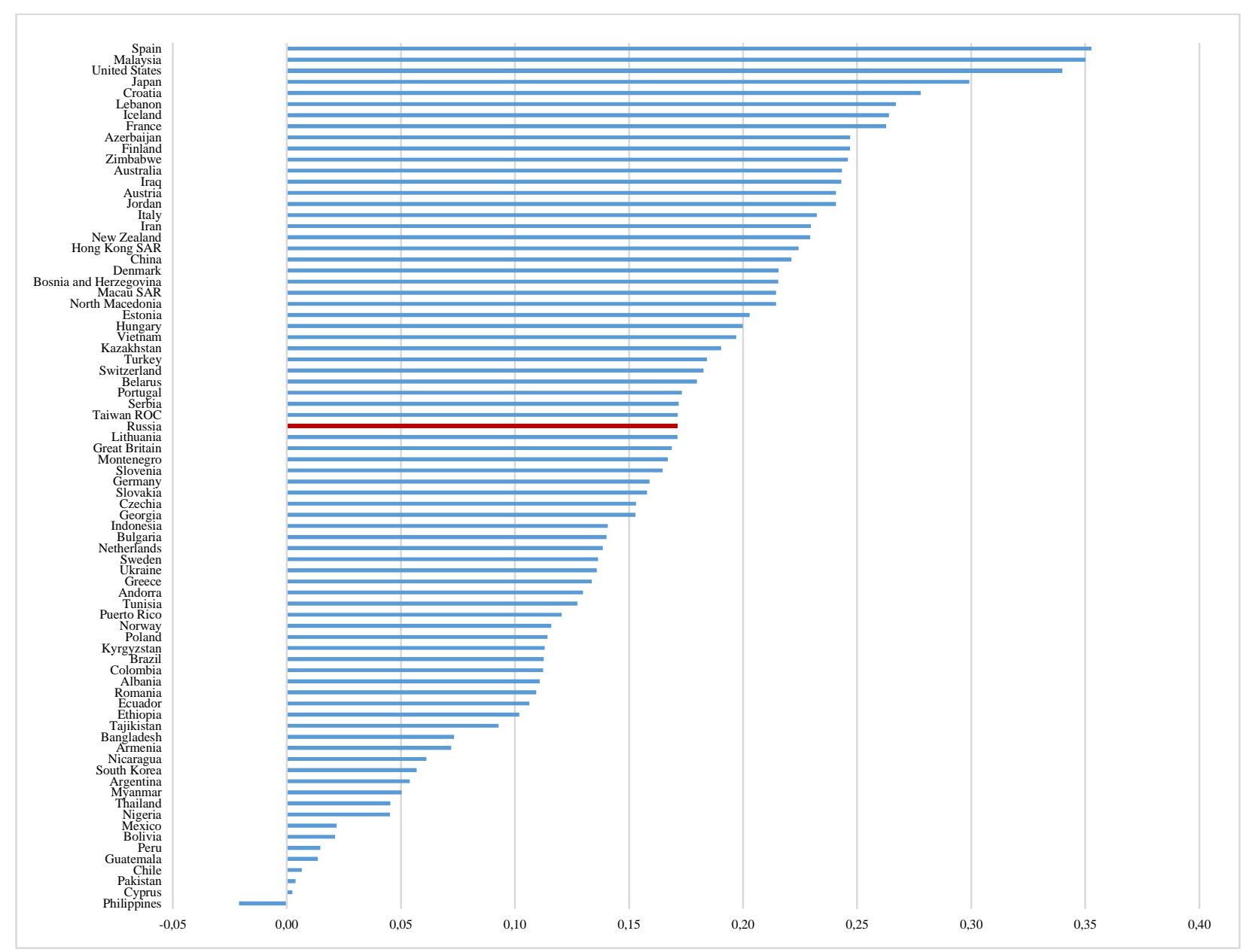

Figure 11. Correlations between national pride and trust in the police by countries

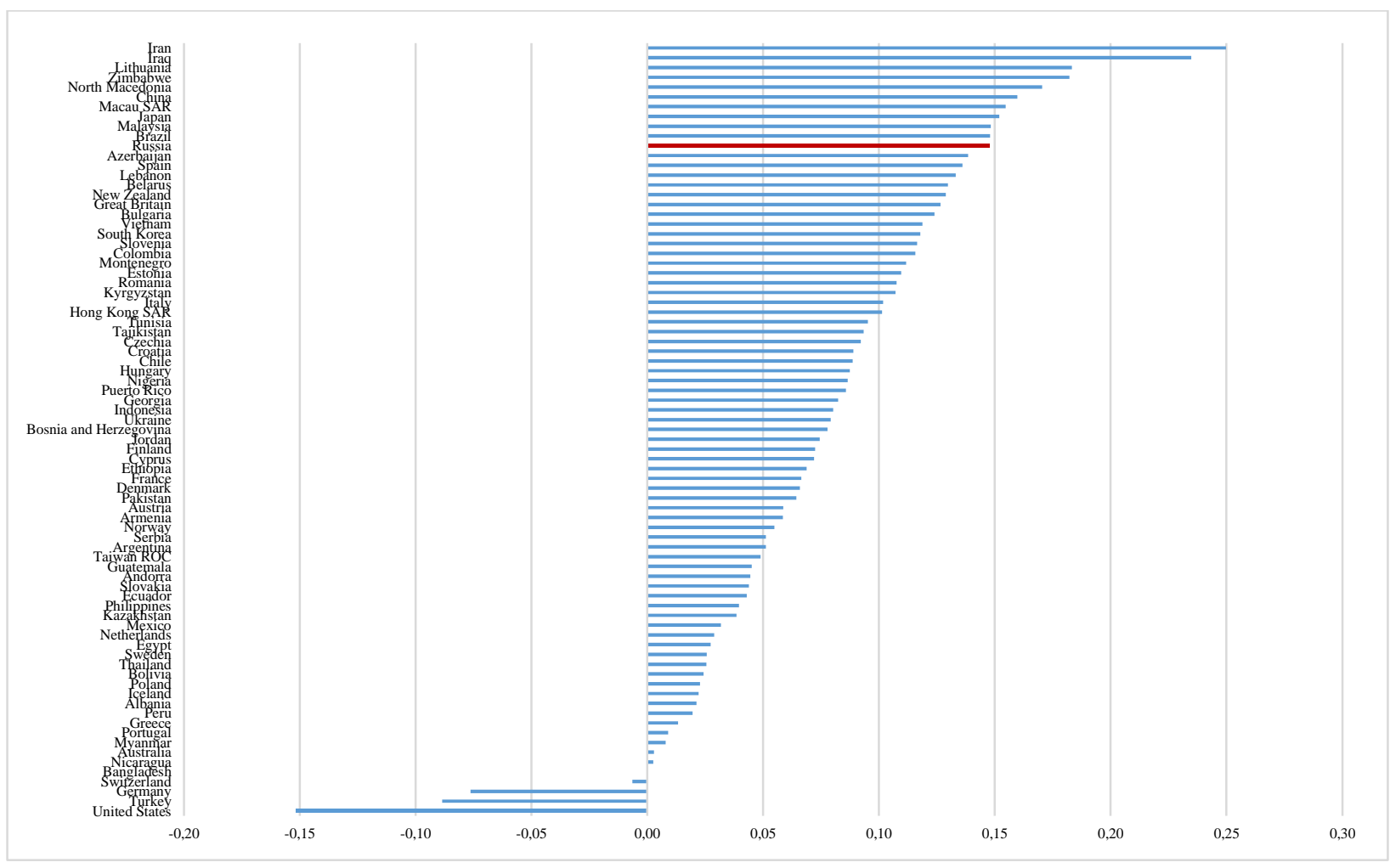

Figure 12. Correlations between national pride and trust in the press by countries 


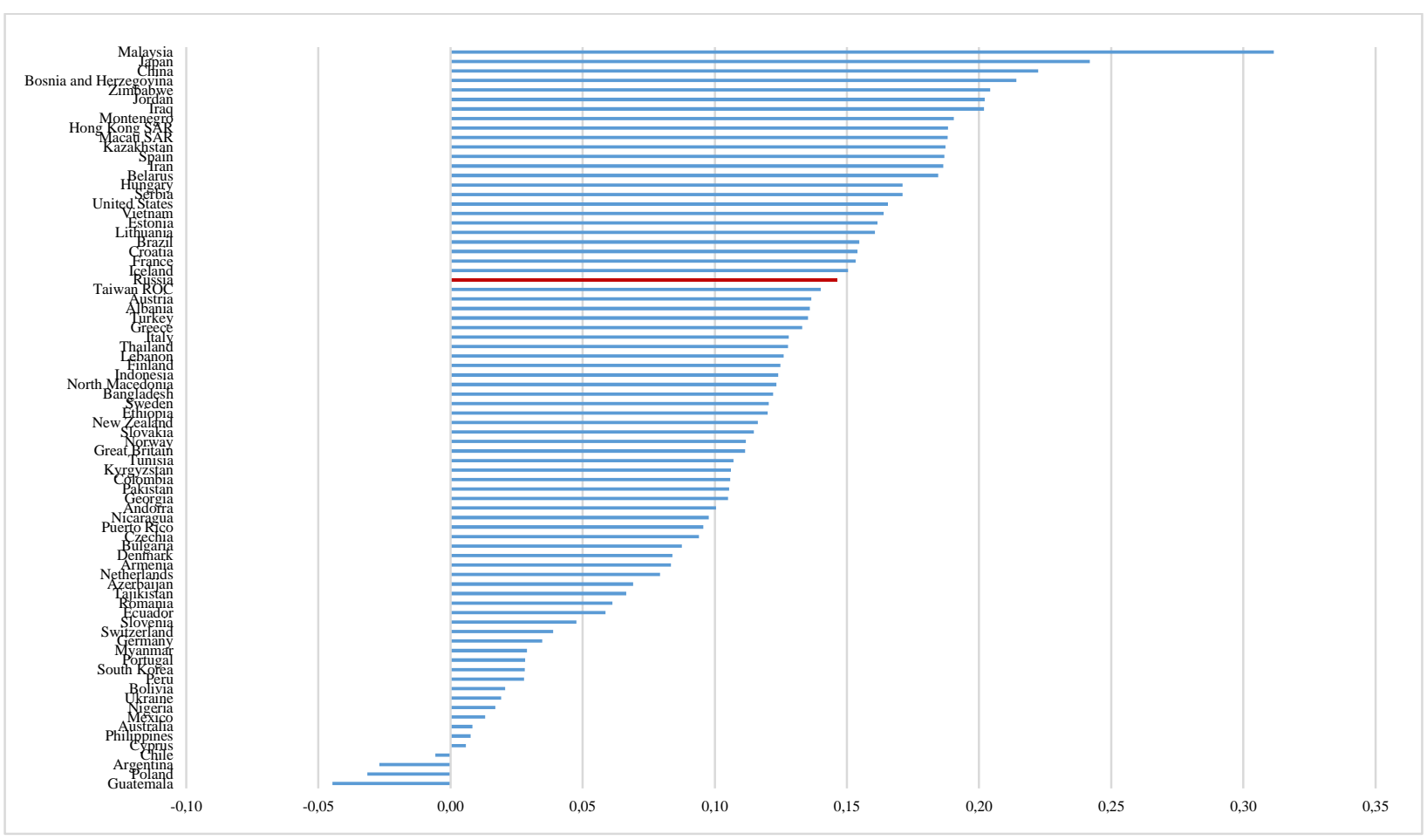

Figure 13. Correlations between national pride and trust in the justice system/courts by countries

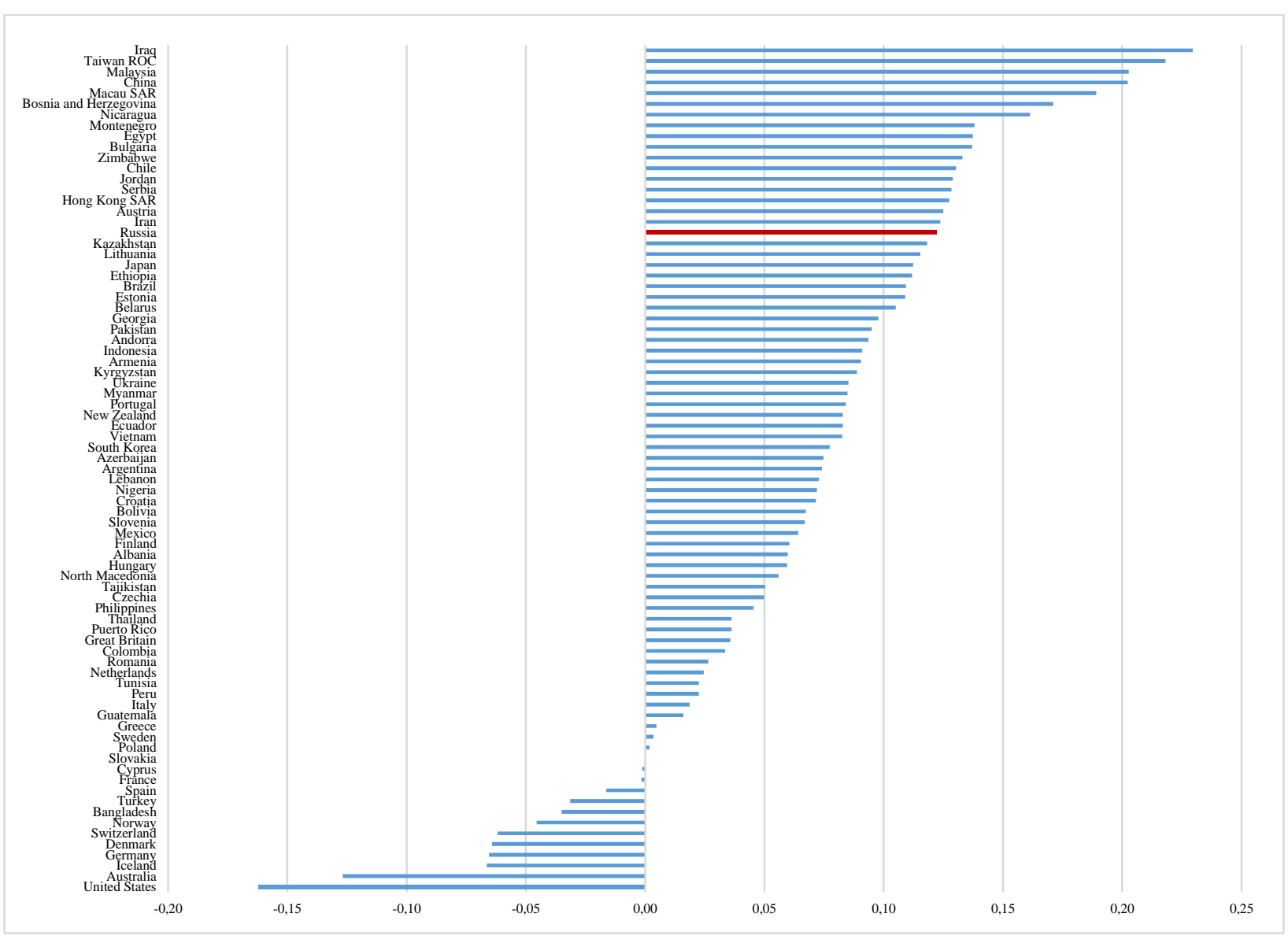

Figure 14. Correlations between national pride and trust in the environment protection movement by countries 


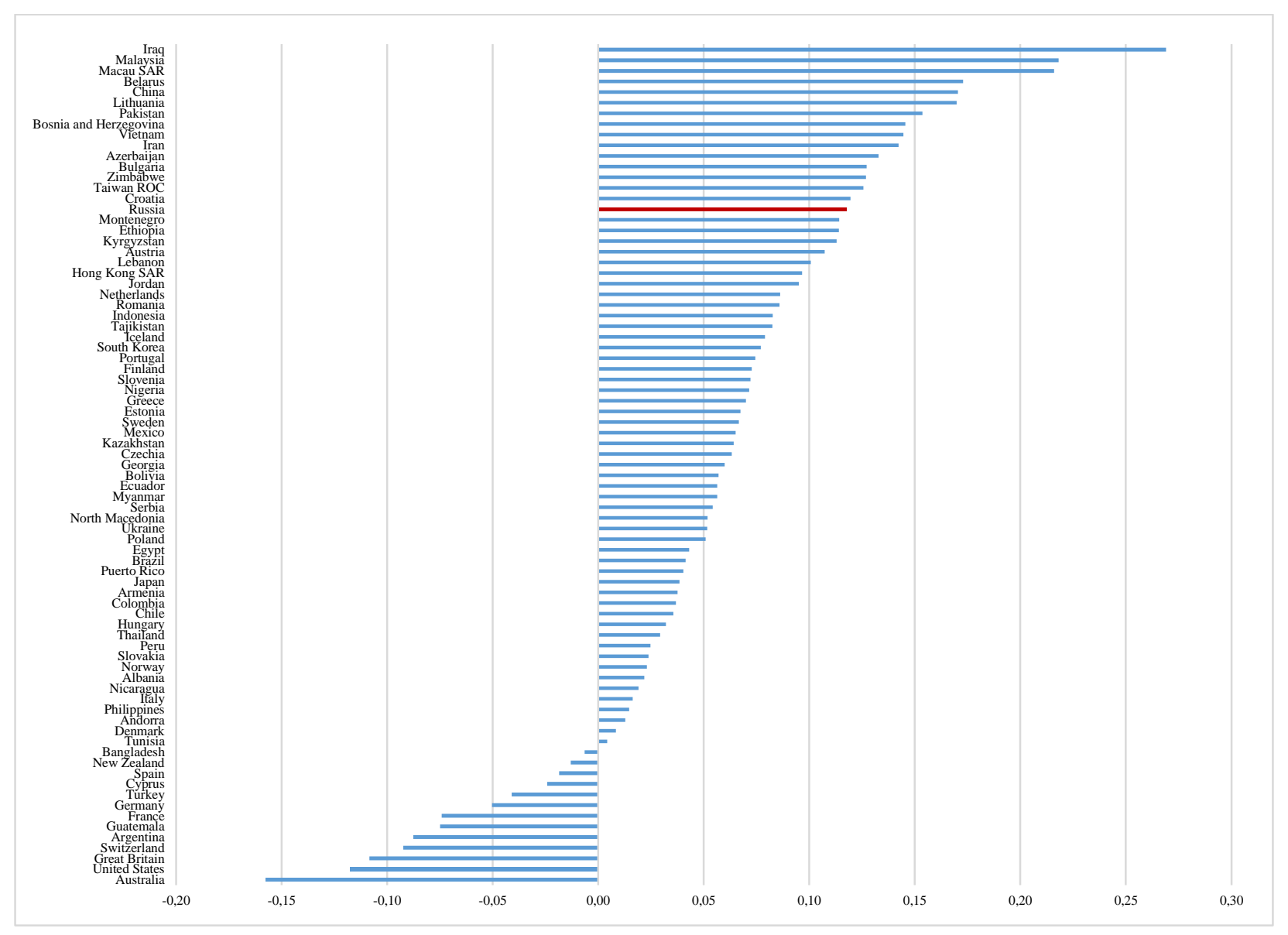

Figure 15. Correlations between national pride and trust in labor unions by countries

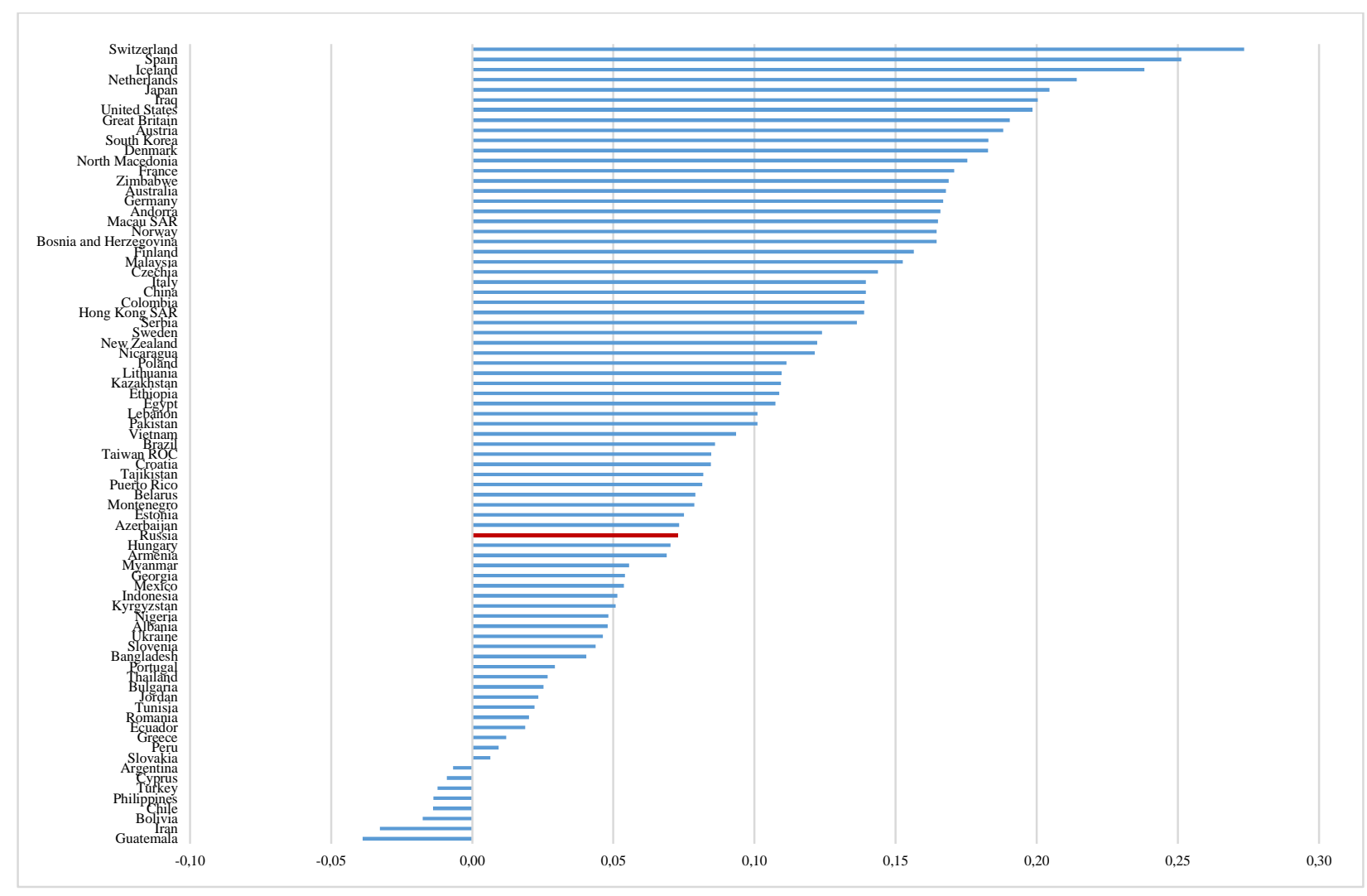

Figure 16. Correlations between national pride and trust in major companies by countries 


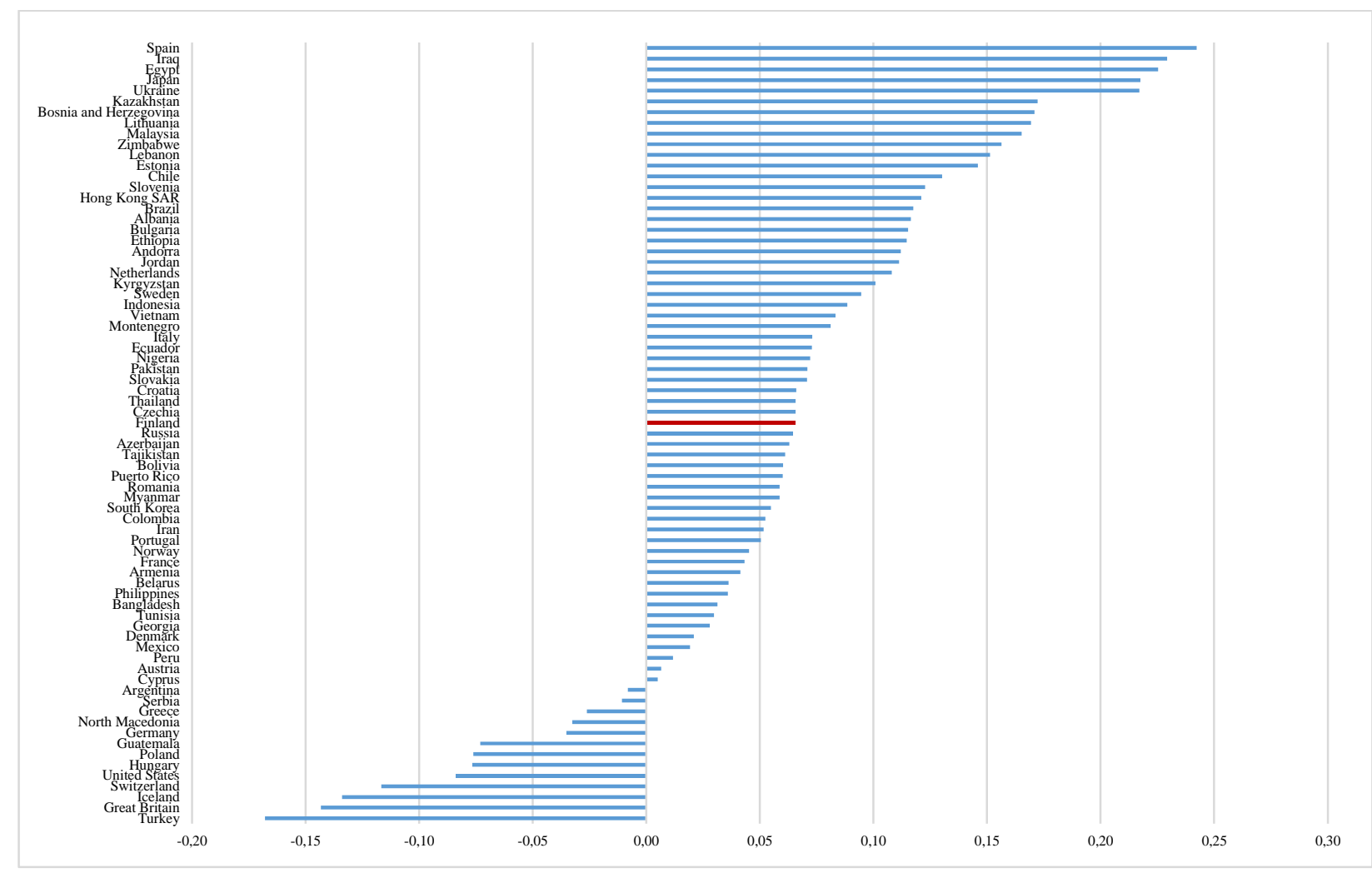

Figure 17. Correlations between national pride and trust in the major regional organization by countries

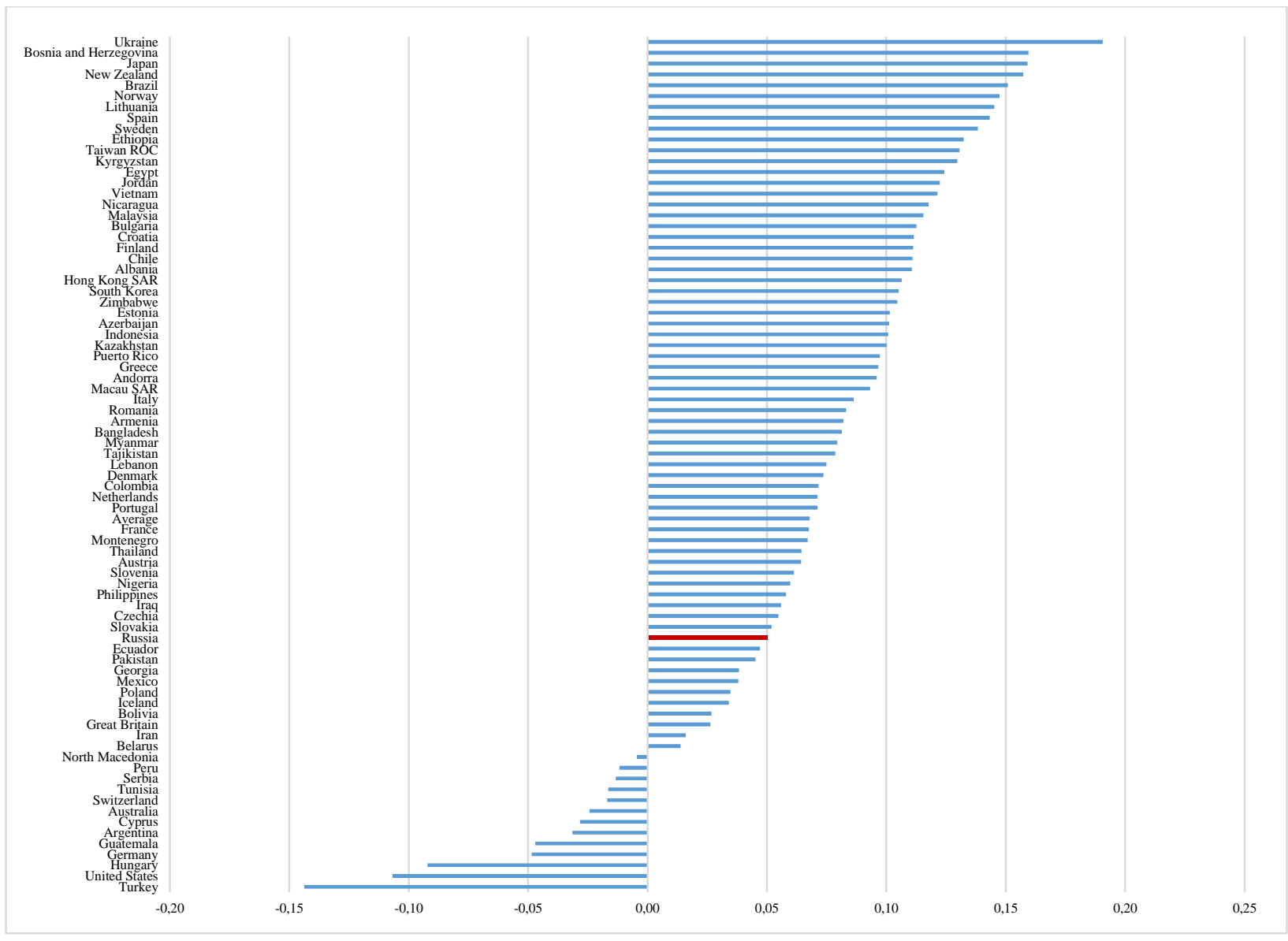

Figure 18. Correlations between national pride and trust in the United Nations by countries 


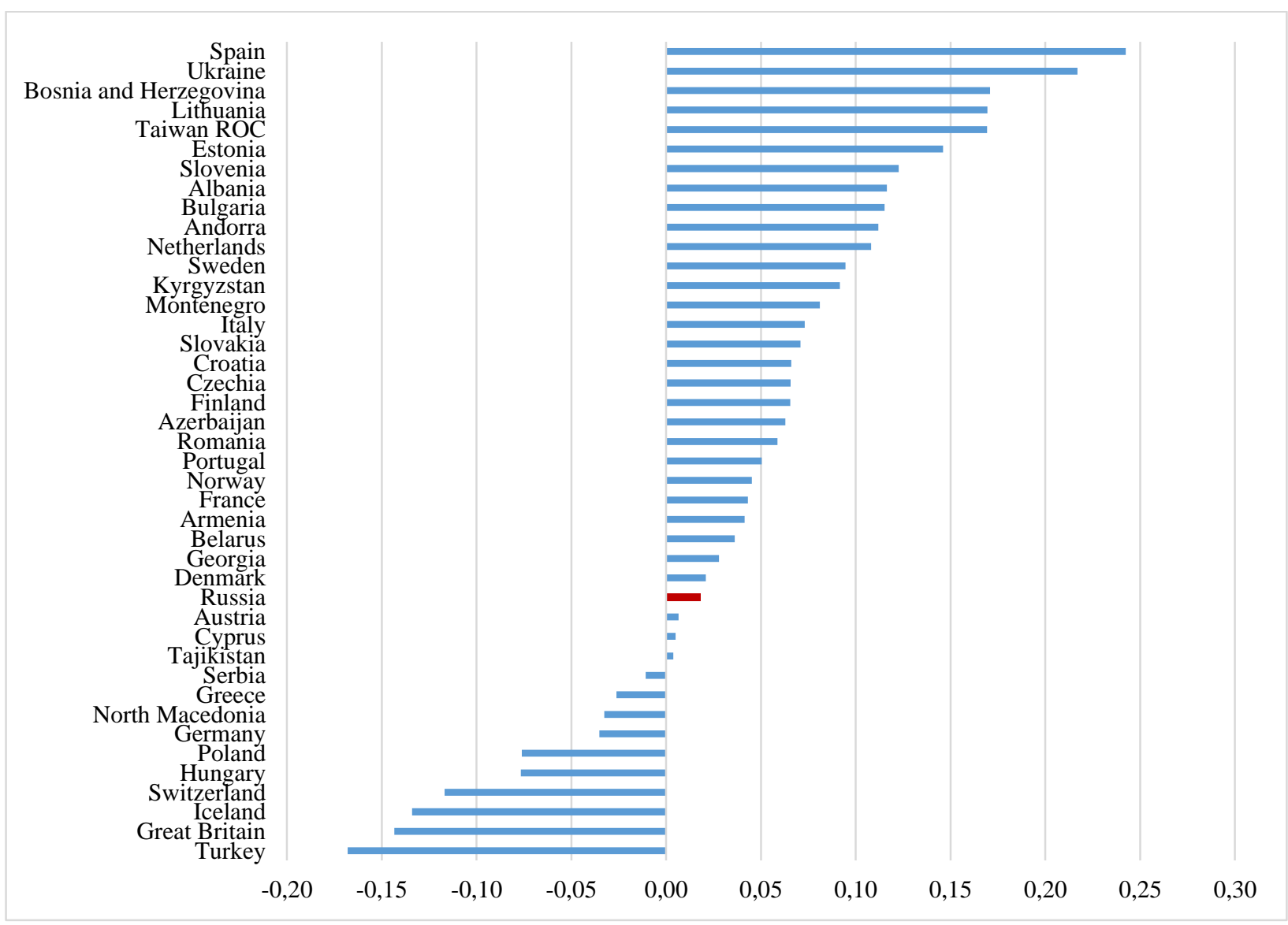

Figure 19. Correlations between national pride and trust in the European Union by countries

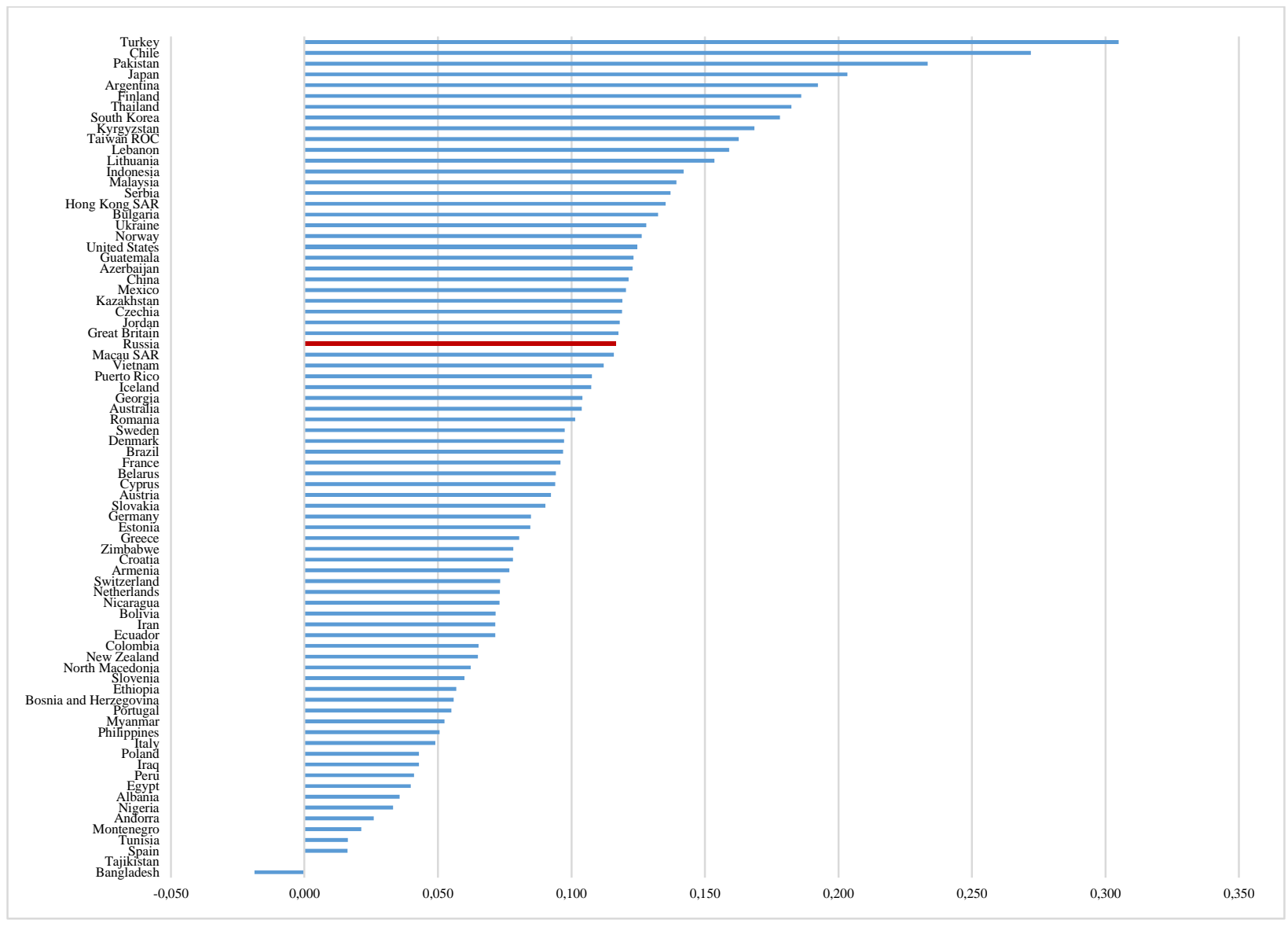

Figure 20. Correlations between national pride and trust in the family by countries 


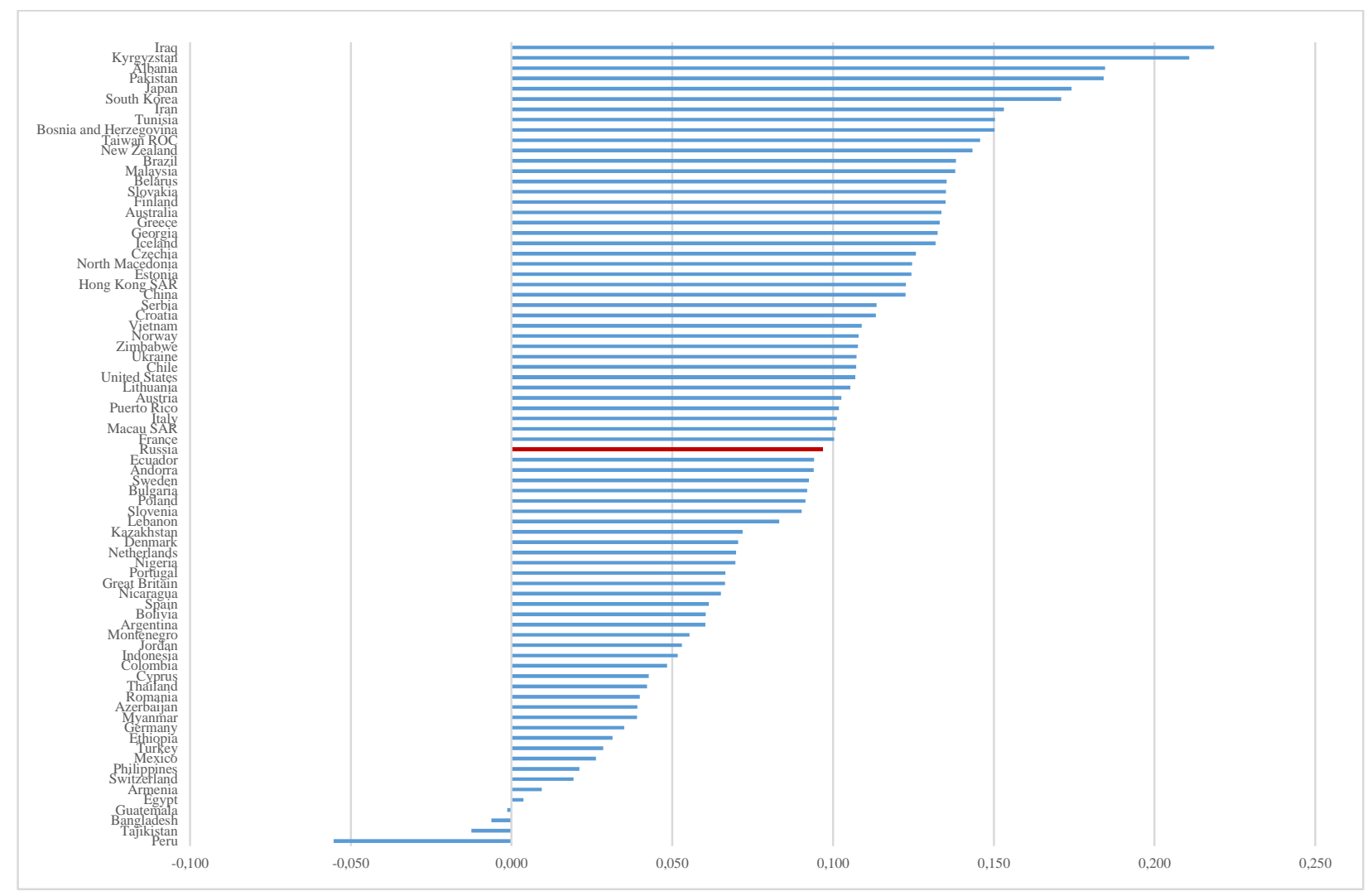

Figure 21. Correlations between national pride and trust in the neighborhood by countries

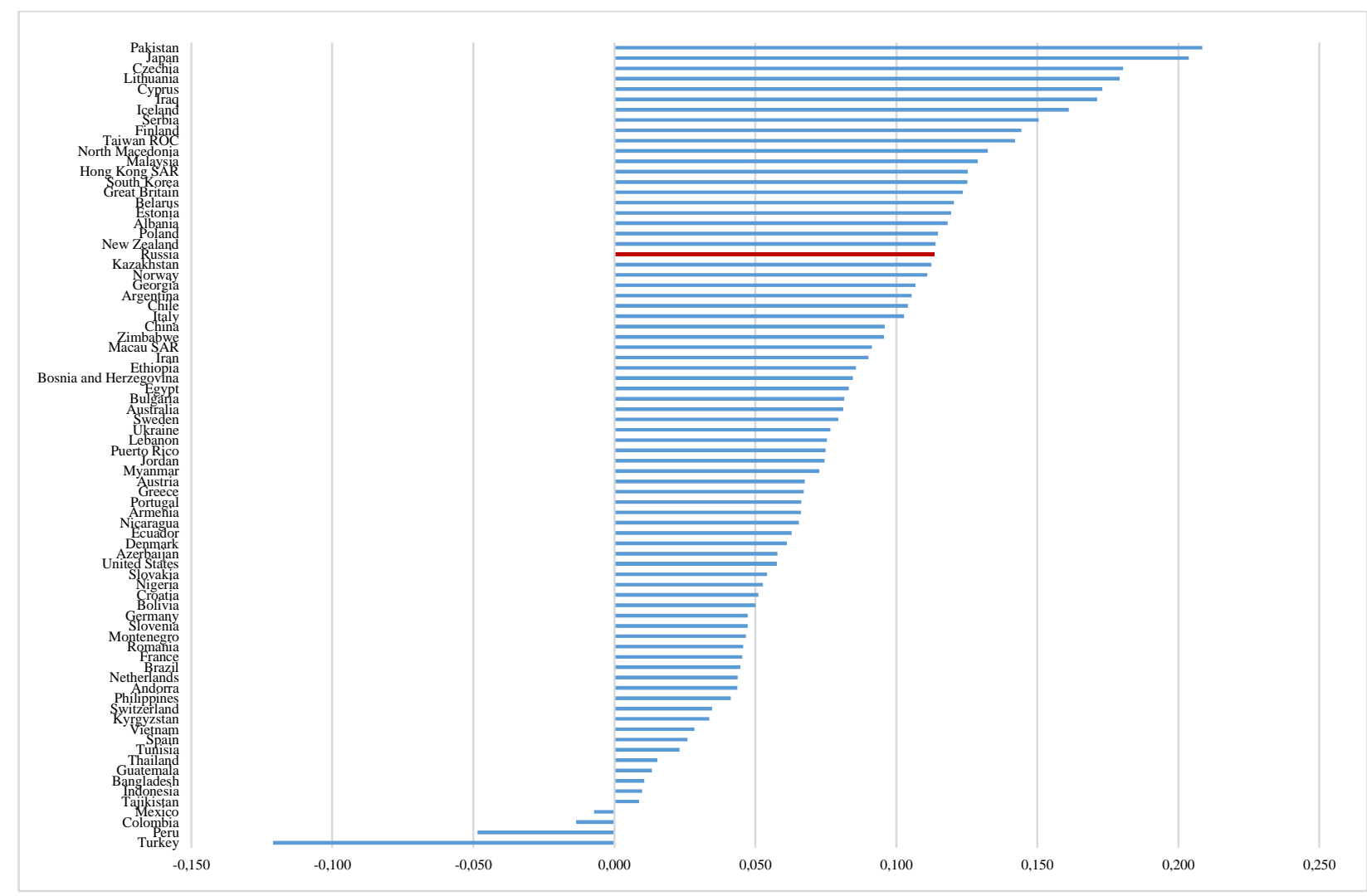

Figure 22. Correlations between national pride and trust in people known personally by countries 


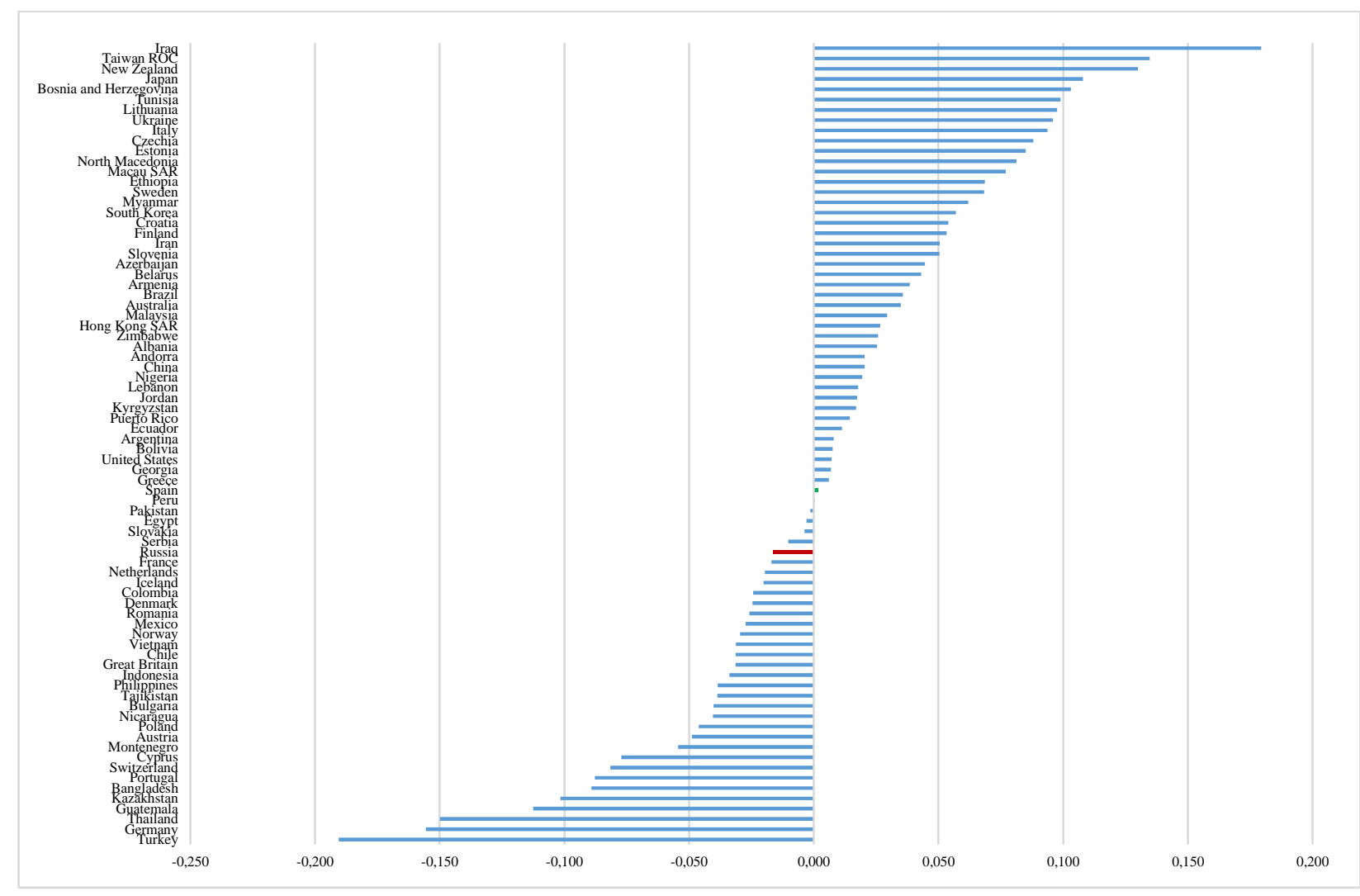

Figure 23. Correlations between national pride and trust in people met for the first time by countries

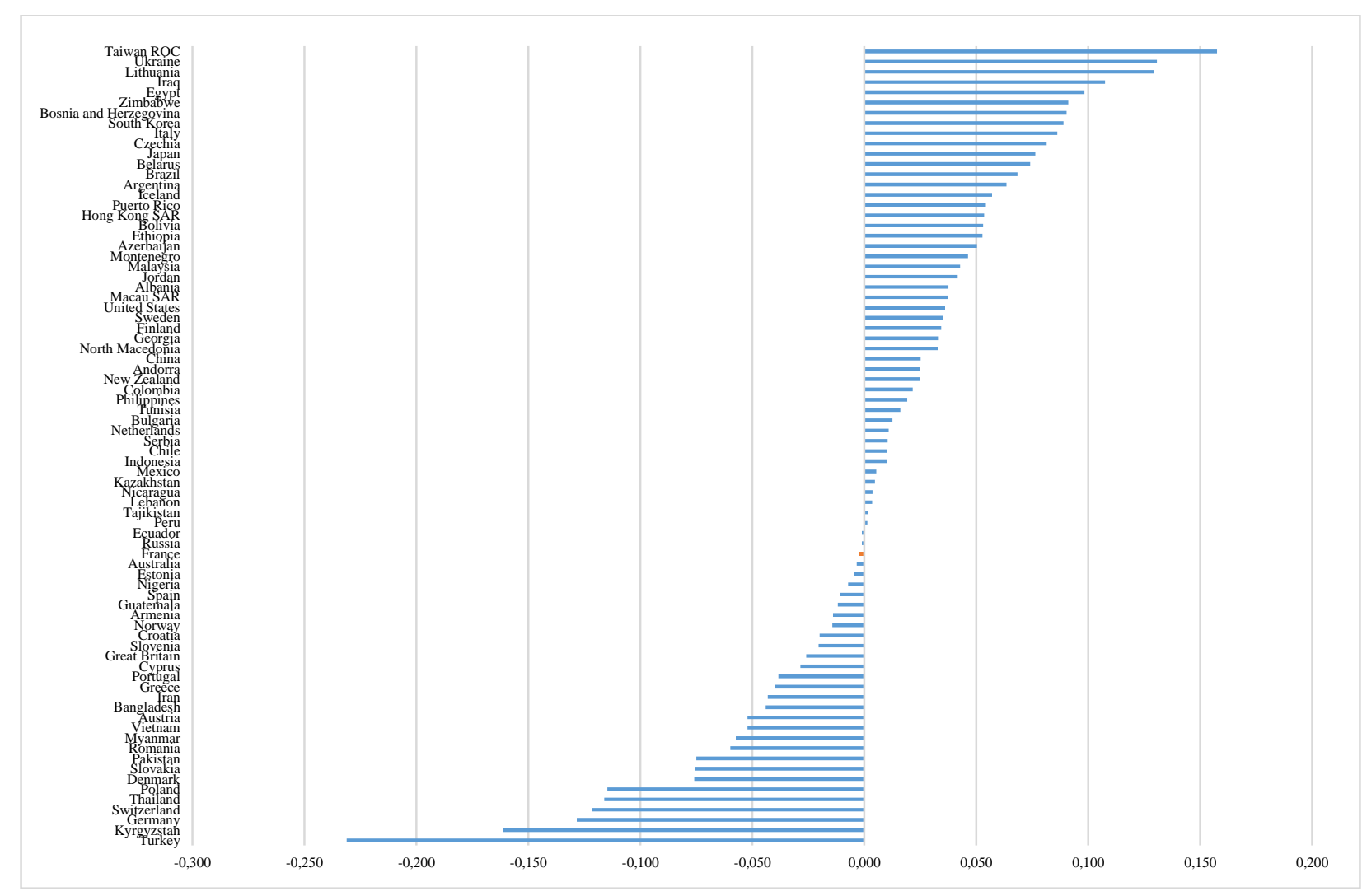

Figure 24. Correlations between national pride and people or another religion by countries 


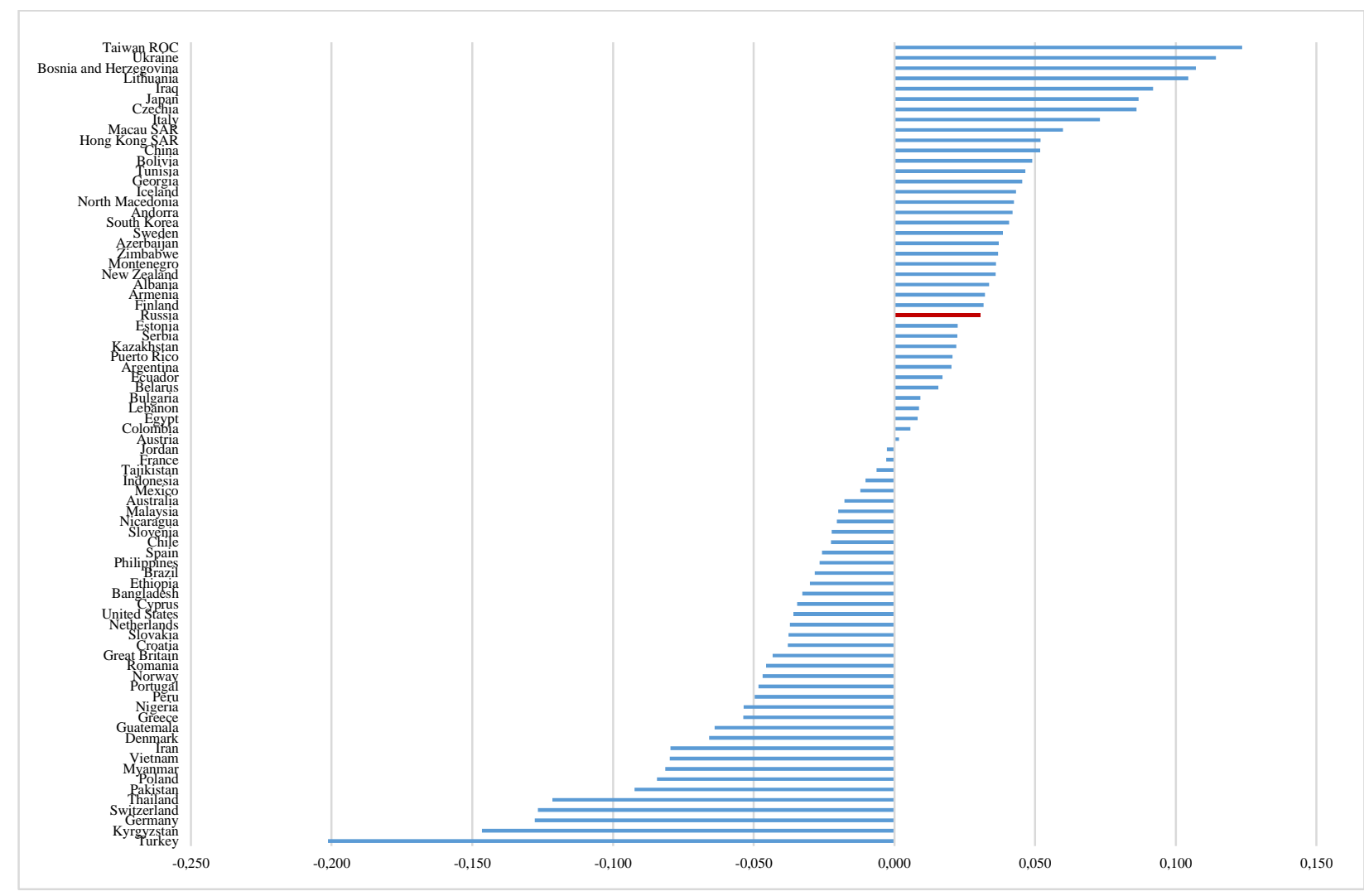

Figure 25. Correlations between national pride and trust in people of another nationality by countries

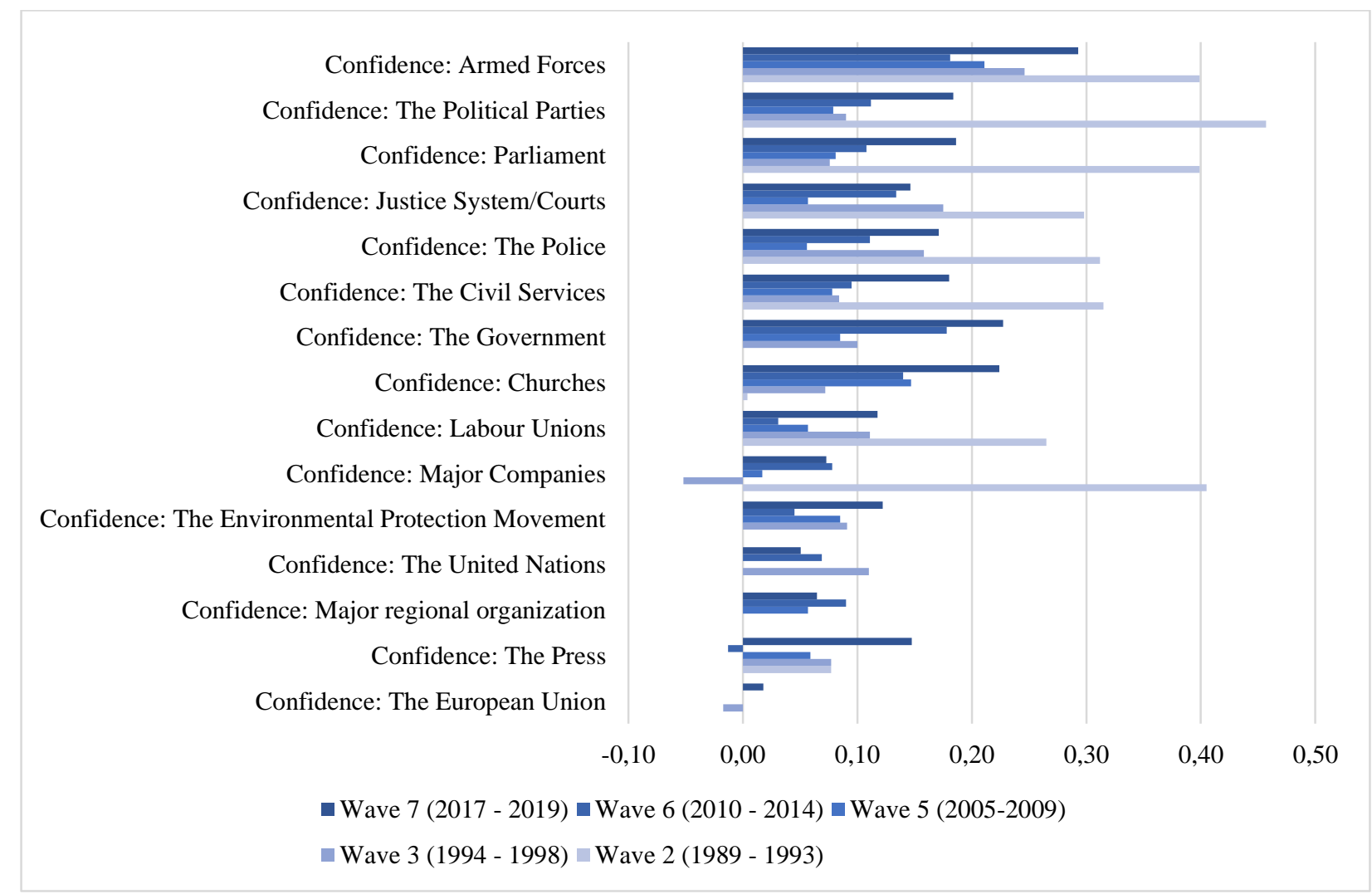

Figure 26. Dynamics of correlations between national pride and institutional trust in Russia 


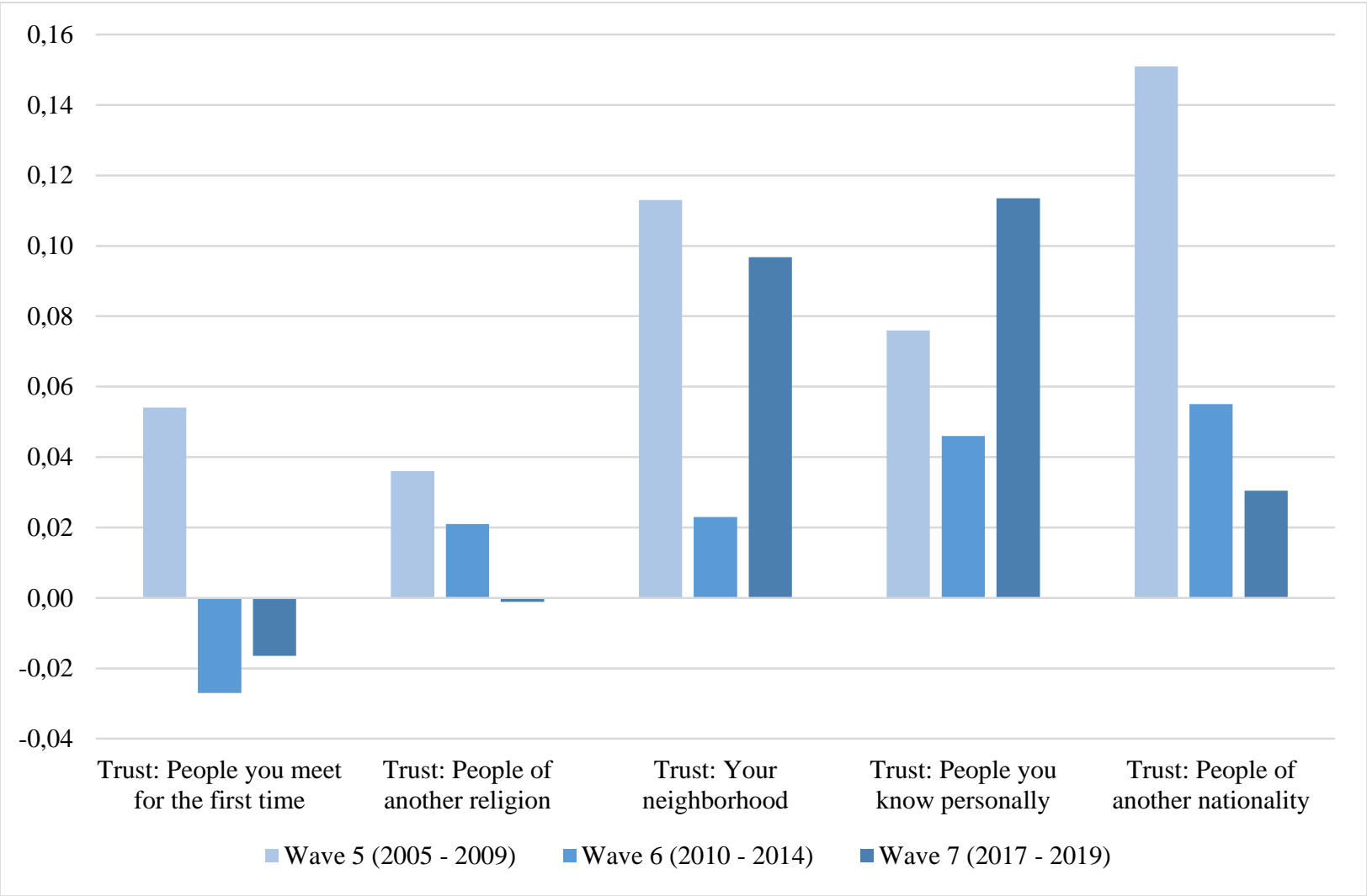

Figure 27. Dynamics of correlations between national pride and interpersonal trust in Russia 
Table 1. Multilevel ordinal logistic regression for institutional trust

\begin{tabular}{|c|c|c|c|c|c|c|c|c|c|c|c|c|c|c|}
\hline & $\begin{array}{l}\text { Confid } \\
\text { ence: } \\
\text { Churc } \\
\text { hes }\end{array}$ & $\begin{array}{l}\text { Confid } \\
\text { ence: } \\
\text { Armed } \\
\text { Forces }\end{array}$ & $\begin{array}{l}\text { Confid } \\
\text { ence: } \\
\text { The } \\
\text { Press }\end{array}$ & $\begin{array}{l}\text { Confid } \\
\text { ence: } \\
\text { Labou } \\
r \\
\text { Union } \\
\text { s }\end{array}$ & $\begin{array}{l}\text { Confid } \\
\text { ence: } \\
\text { The } \\
\text { Police }\end{array}$ & $\begin{array}{l}\text { Confid } \\
\text { ence: } \\
\text { Parlia } \\
\text { ment }\end{array}$ & $\begin{array}{l}\text { Confid } \\
\text { ence: } \\
\text { The } \\
\text { Civil } \\
\text { Servic } \\
\text { es }\end{array}$ & $\begin{array}{l}\text { Confid } \\
\text { ence: } \\
\text { Major } \\
\text { region } \\
\text { al } \\
\text { organi } \\
\text { zation }\end{array}$ & $\begin{array}{l}\text { Confid } \\
\text { ence: } \\
\text { The } \\
\text { Gover } \\
\text { nment }\end{array}$ & $\begin{array}{l}\text { Confid } \\
\text { ence: } \\
\text { The } \\
\text { Politic } \\
\text { al } \\
\text { Parties }\end{array}$ & $\begin{array}{l}\text { Confid } \\
\text { ence: } \\
\text { Major } \\
\text { Comp } \\
\text { anies }\end{array}$ & $\begin{array}{l}\text { Confide } \\
\text { nce: The } \\
\text { Environ } \\
\text { mental } \\
\text { Protecti } \\
\text { on } \\
\text { Movem } \\
\text { ent }\end{array}$ & $\begin{array}{c}\text { Confide } \\
\text { nce: } \\
\text { Justice } \\
\text { System/ } \\
\text { Courts }\end{array}$ & $\begin{array}{c}\text { Confid } \\
\text { ence: } \\
\text { The } \\
\text { United } \\
\text { Nation } \\
\text { s }\end{array}$ \\
\hline \multicolumn{15}{|c|}{ Individual level predictors } \\
\hline Age & $0.008^{* * *}$ & $0.007^{* * *}$ & $0.006^{* * *}$ & -0.001 & $0.003 * * *$ & 0.000 & $0.002 * * *$ & $-0.003 * * *$ & $0.004 * * *$ & -0.000 & -0000 & $-0.005^{* * * *}$ & $-0.002 * * *$ & $-0.005^{* * *}$ \\
\hline $\begin{array}{l}\text { Gender female } \\
\text { (ref male) }\end{array}$ & $0.158^{* * * *}$ & $-0.209 * * *$ & -0.025 & 0.005 & $0.062 * * *$ & 0.019 & 0.007 & 0.019 & 0.024 & 0.021 & -0.040 ** & $0.049 * *$ & $0.037^{*}$ & $0.054 * * *$ \\
\hline Education & $-0.061 * * *$ & $-0.033^{* * *}$ & $-0.022 * * *$ & -0.007 & $-0.048^{* * *}$ & $-0.039^{* * * *}$ & $-0.012 * *$ & $0.018 * * *$ & $-0.060^{* * * *}$ & $-0.057^{* * *}$ & $-0.009 *$ & -0.004 & $-0.035 * * *$ & $0.034 * * *$ \\
\hline Income & $0.011^{* *}$ & 0.006 & $0.023^{* * *}$ & $0.020^{* * *}$ & $0.034 * * *$ & $0.029^{* * * *}$ & $0.034 * * *$ & $0.041 * * *$ & $0.029 * * *$ & $0.040^{* * * *}$ & $0.051^{* * *}$ & $0.016 * * *$ & $0.034 * * *$ & $0.031 * * *$ \\
\hline National pride & $0.307^{* * * *}$ & $0.432^{* * * *}$ & $0.400^{* * *}$ & $0.420^{* * * *}$ & $0.258^{* * *}$ & $0.347^{* * * *}$ & $0.387^{* * * *}$ & $0.341^{* * * *}$ & $0.364 * * *$ & $0.242^{* * * *}$ & $0.205^{* * *}$ & $0.455^{* * * *}$ & $0.379^{* * *}$ & $0.297^{* * *}$ \\
\hline \multicolumn{15}{|c|}{ Country level predictors } \\
\hline IHDI & $-6.021 * * *$ & 0.006 & $2.030^{* *}$ & $2.325 * *$ & $1.840^{*}$ & 0.796 & 1.742 & 1.444 & -0.885 & 0.854 & -1.159 & $2.938 * * *$ & $2.114^{*}$ & 1.714 \\
\hline \multicolumn{15}{|c|}{ Cross-level interaction effects } \\
\hline $\begin{array}{l}\text { National pride } \\
* \text { IHDI }\end{array}$ & 0.079 & $0.227^{* *}$ & $-0.688 * * *$ & $-0.855^{* * *}$ & $0.399 * * *$ & -0.154 & $-0.289^{* * * *}$ & $-0.510^{* * * *}$ & 0.108 & -0.002 & 0.079 & $-0.797^{* * * *}$ & $-0.214^{*}$ & $-0.458 * * *$ \\
\hline $\begin{array}{l}\text { 2log } \\
\text { Likelihood }\end{array}$ & -69704.80 & -67278.65 & -72881.29 & -68829.56 & -72209.84 & -67467.19 & -68467.89 & -57357.24 & -70686.22 & -65639.64 & -70133.17 & -70831.53 & -71660.33 & -62119.42 \\
\hline$A I C$ & 139431.60 & 134579.5 & 145784.57 & 137681.12 & 144441.68 & 134956.4 & 136957.78 & 114736.84 & 141384.44 & 131301.28 & 140288.35 & 141685.06 & 143342.66 & 128260.84 \\
\hline$B I C$ & 139530.9 & 134678.5 & 145883.8 & 137779.8 & 144540.8 & 135055.5 & 137056.9 & 114832.9 & 141493.5 & 131400.4 & 140387.4 & 141783.8 & 143441.7 & 128358.3 \\
\hline
\end{tabular}


Table 2. Multilevel ordinal logistic regression for interpersonal trust

\begin{tabular}{|c|c|c|c|c|c|c|}
\hline & $\begin{array}{l}\text { Trust: } \\
\text { Your } \\
\text { family }\end{array}$ & $\begin{array}{c}\text { Trust: Your } \\
\text { neighborhood }\end{array}$ & $\begin{array}{c}\text { Trust: } \\
\text { People } \\
\text { you know } \\
\text { personally }\end{array}$ & $\begin{array}{l}\text { Trust: } \\
\text { People } \\
\text { you meet } \\
\text { for the } \\
\text { first time }\end{array}$ & $\begin{array}{l}\text { Trust: } \\
\text { People of } \\
\text { another } \\
\text { religion }\end{array}$ & $\begin{array}{c}\text { Trust: } \\
\text { People of } \\
\text { another } \\
\text { nationality }\end{array}$ \\
\hline \multicolumn{7}{|c|}{ Individual level predictors } \\
\hline Age & 0.001 & $0.014 * * *$ & $0.004 * * *$ & $0.007 * * *$ & $0.005^{* * *}$ & $0.004 * * *$ \\
\hline gender & $0.108 * * *$ & $-0.173 * * *$ & $-0.104 * * *$ & $-0.161 * * *$ & $-0.119^{* * *}$ & $-0.136^{* * *}$ \\
\hline Education & $0.047 * * *$ & -0.006 & $0.046^{* * *}$ & $0.024 * * *$ & $0.089 * * *$ & $0.101 * * *$ \\
\hline Income & $0.039 * * *$ & $0.028 * * *$ & $0.038^{* * *}$ & $0.047 * * *$ & $0.034 * * *$ & $0.045^{* * *}$ \\
\hline National pride & $0.314 * * *$ & $0.290 * * *$ & $0.223 * * *$ & 0.021 & 0.043 & $-0.078 * *$ \\
\hline \multicolumn{7}{|l|}{ Country level predictors } \\
\hline IHDI & -0.775 & 0.489 & $2.371^{* *}$ & $1.521 *$ & 1.435 & $2.455^{* * *}$ \\
\hline \multicolumn{7}{|c|}{ Cross-level interaction effects } \\
\hline National pride * IHDI & $0.282 * *$ & $-0.206^{*}$ & -0.138 & $-0.167 *$ & -0.124 & 0.094 \\
\hline 2log Likelihood & 37996.07 & -68611.28 & -68180.37 & -67535.1 & -70292.15 & -68205.73 \\
\hline$A I C$ & 75954.14 & 137244.56 & 136382.73 & 135092.03 & 140606.30 & 136433.49 \\
\hline$B I C$ & 76053.56 & 137343.9 & 136482.1 & 135191.3 & 140705.3 & 136532.5 \\
\hline
\end{tabular}

